\title{
Summertime primary production and carbon export in the southeastern Beaufort Sea during the low ice year of 2008
}

\author{
Amélie Sallon • Christine Michel • Michel Gosselin
}

Received: 30 September 2010/Revised: 13 June 2011/Accepted: 22 June 2011/Published online: 2 August 2011

(C) The Author(s) 2011. This article is published with open access at Springerlink.com

\begin{abstract}
Following the extreme low ice year of 2007, primary production and the sinking export of particulate and gel-like organic material, using short-term particle interceptor traps deployed at $100 \mathrm{~m}$, were measured in the southeastern Beaufort Sea during summer 2008. The combined influence of early ice retreat and coastal upwelling contributed to exceptionally high primary production $\left(500 \pm 312 \mathrm{mg} \mathrm{C} \mathrm{m}^{-2}\right.$ day $\left.^{-1}, n=7\right)$, dominated by large cells $(>5 \mu \mathrm{m}, 73 \% \pm 15 \%, n=7)$. However, except for one station located north of Cape Bathurst, the sinking export of particulate organic carbon (POC) was relatively low (range: $38-104 \mathrm{mg} \mathrm{C} \mathrm{m}^{-2}$ day $^{-1}, n=12$ ) compared to other productive Arctic shelves. Estimates indicate that $80 \% \pm 20 \%$ of the primary production was cycled through large copepods or the microbial food web. Exopolymeric substances were abundant in the sinking material but did not appear to accelerate POC sinking export. The use of isotopic signatures $\left(\delta^{13} \mathrm{C}, \delta^{15} \mathrm{~N}\right)$ and carbon/nitrogen ratios to identify sources of the sinking material was successful only at two stations with a strong marine or terrestrial signature, indicating the limitations of this approach in hydrographically and biologically complex Arctic coastal waters such as in the Beaufort Sea. At
\end{abstract}

This article belongs to the special issue "Circumpolar Flaw Lead Study (CFL)," coordinated by J. Deming and L. Fortier.

A. Sallon $(\bowtie) \cdot$ M. Gosselin

Institut des sciences de la mer (ISMER), Université du Québec à

Rimouski, 310 Allée des Ursulines, Rimouski,

QC G5L 3A1, Canada

e-mail: sallon.amelie@gmail.com

A. Sallon - C. Michel

Freshwater Institute, Fisheries and Oceans Canada,

501 University Crescent, Winnipeg, MB R3T 2N6, Canada these two stations influenced by either coastal upwelling or erosion, the composition and magnitude of particulate sinking fluxes were markedly different from other stations visited during the study. These observations underscore the fundamental role of mesoscale circulation patterns and hydrodynamic singularities on the export of particulate organic material on Arctic shelves.

Keywords Sedimentation - Primary production · Carbon - Exopolymeric substances - Stable isotopes . Beaufort Sea $\cdot$ Arctic

\section{Introduction}

Global warming is intensified in the Arctic (IPCC 2007; Kauffmann et al. 2009). Models and observations show a rapid decline in the summer minimum sea ice extent over the past ten years (Serreze et al. 2007; Barber et al. 2009; Wang and Overland 2009; Polyak et al. 2010) and an increase in the extent and duration of open water areas (Comiso et al. 2008; Pabi et al. 2008). Climate-related impacts on the biodiversity, ecosystem structure (Gradinger and Bluhm 2005; Grebmeier et al. 2006), from planktonic communities to large mammals (Wassmann et al. 2011) and on pathways of carbon cycling (Wassmann et al. 2004) are already documented for the Arctic Ocean.

The variety of responses of the marine Arctic to ongoing changes makes it difficult to predict the magnitude, let alone the direction, of potential impacts of climateassociated changes for the transfer of primary-produced organic matter to pelagic and benthic food webs. For example, while an increase in primary production has been associated with an increased duration of the open water period (Arrigo et al. 2008), a shift in phytoplankton 
community structure, from a dominance of large cells to small cells, has also been observed ( $\mathrm{Li}$ et al. 2009). Other studies conclude that global phytoplankton concentrations have declined over the past century, associated with increasing sea surface temperature and shallowing of the surface mixed layer (Montes-Hugo et al. 2009; Boyce et al. 2010, 2011). In the Arctic, it has been suggested that warming and shallowing of the mixed layer will increase the flow of carbon toward the microbial food web at the expense of larger organisms (Kirchman et al. 2009). Contrasting this perspective, other studies suggest that an increase in primary production associated with the decrease in sea ice extent will increase the vertical export of particulate organic carbon to the benthos, as observed in the northern Laptev Sea (Lalande et al. 2009a, b).

To complicate matters further, the coupling between surface primary production and its export to the seafloor not only depends on the magnitude and composition of primary-produced material but also on the transformation of this material during its descent, which itself is dependent on physical and biological processes (e.g., Tréguer et al. 2003; Boyd and Trull 2007; Buesseler and Boyd 2009). For example, bacteria play a key role in controlling carbon fluxes in the ocean through their production and consumption of dissolved organic matter, respiratory $\mathrm{CO}_{2}$ production, and nutrient recycling (Rivkin and Legendre 2001; Kirchman et al. 2009; Kellogg et al. 2011). The production of exopolymeric substances by phytoplankton and bacteria can also accelerate (Passow and Alldredge 1994; Verdugo et al. 2004) or decrease (Azetsu-Scott and Passow 2004) the sinking export of organic carbon to depth.

The Arctic Ocean, on a volumetric basis, is the ocean with the highest terrestrial input in terms of freshwater and organic matter (Dittmar and Kattner 2003). The Mackenzie River, flowing into the southeastern Beaufort Sea, is the fourth largest of all rivers entering the Arctic Ocean, in terms of annual discharge of water (Dittmar and Kattner 2003) and the first in terms of sediment input to the Arctic (Rachold et al. 2004). Therefore, the vertical flux of particles in the southeastern Beaufort Sea derives primarily from three sources: marine biological production, input from the Mackenzie River, and coastal and seabed erosion (O'Brien et al. 2006). Global warming in the Arctic Ocean is leading to accelerated coastal erosion (Carmack and Macdonald 2002; Guo et al. 2007) and increased river discharge (Holmes et al. 2002; Peterson et al. 2002; White et al. 2007), such that an increase in the input of allochthonous material is expected in Arctic shelves (Guo et al. 2007; Lalande et al. 2009a; Mucci et al. 2010). Tracers such as stable isotopes $\left(\delta^{13} \mathrm{C}\right.$ and $\left.\delta^{15} \mathrm{~N}\right)$ and compositional ratios (e.g., carbon/nitrogen ratios) are commonly used to distinguish between marine and terrigenous organic matter in sediments and sinking matter (Macdonald et al. 2004; Morata et al. 2008; Magen et al. 2010).

The exceptional decline in the sea ice extent in summers 2007 and 2008 (Comiso et al. 2008; Stroeve et al. 2008; NSIDC 2010), the increase Arctic river discharge (Holmes et al. 2002; Peterson et al. 2002; White et al. 2007), the increase in frequency and intensity of storms (Yang et al. 2004; Barber et al. 2008), the sea surface warming (Steele et al. 2008), and the thawing of permafrost (Camill 2005) are all evidences of global warming in Arctic. These changes stress the need to better understand biogenic carbon cycling and energy transfer pathways on Arctic shelves and to study the impact of the recent intensification of environmental changes taking place in the Arctic.

The overall objective of this study was to investigate primary production and carbon export in the southeastern Beaufort Sea, in summer 2008 (which proved to be a low ice year) following the extreme low ice year of 2007. Specific objectives were to (1) characterize spatial and temporal patterns in the magnitude and composition of particulate organic material (POM) exported from the euphotic zone and evaluate recent changes with respect to previous observations in the same area and (2) identify sources of the sinking organic material (allochthonous vs autochthonous) in the study area. We hypothesized that in the study area (1) changes in primary production associated with recent changes in sea ice conditions influenced the vertical export of organic material and (2) the sinking organic material would mainly be of allochthonous origin at coastal stations due to increased coastal erosion.

\section{Materials and methods}

\section{Sampling}

This study was carried out on board the Canadian research icebreaker CCGS Amundsen under the Framework of the International Polar Year, Circumpolar Flaw Lead (CFL) system study (Barber et al. 2010). Short-term free-drifting particle interceptor traps were deployed below the euphotic zone at $100 \mathrm{~m}$, on 12 occasions in the southeastern Beaufort Sea, from June 23 to July 30, 2008, over two sampling periods (late June/early July and late July) (Fig. 1 and Table 1). The euphotic zone depth $\left(Z_{\text {eu }}\right)$, defined as the depth receiving $0.2 \%$ of surface irradiance, was determined from the attenuation of incident photosynthetically active radiation $\left(E_{\mathrm{d}}(\mathrm{PAR}) ; 400-700 \mathrm{~nm}\right)$, measured with a PNF300 radiometer (Biospherical Instruments) (Tremblay et al. 2009). During summer $2008, Z_{\text {eu }}$ ranged from 54 to $108 \mathrm{~m}$, with a mean of $84 \pm 17 \mathrm{~m}$ (Table $1, n=12$ ). The depth of the surface mixed layer $\left(Z_{\text {mix }}\right)$ was determined as the depth of shallowest extreme curvature of density and temperature 


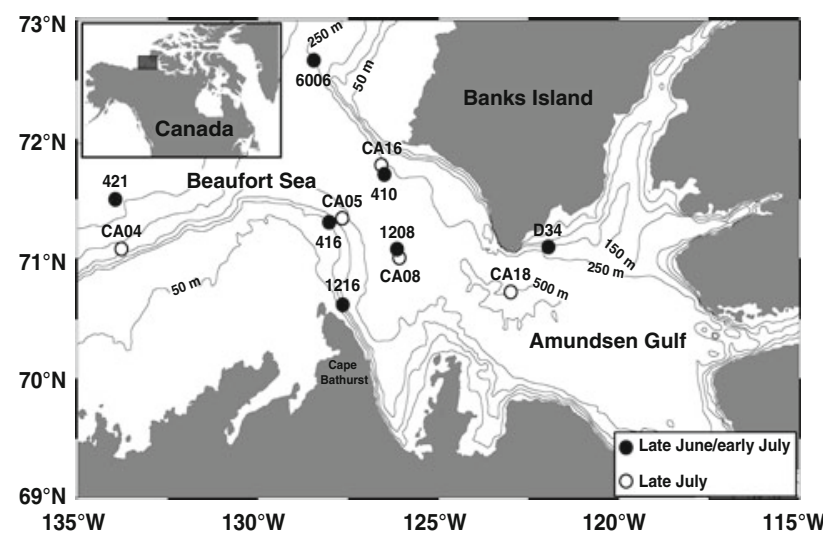

Fig. 1 Location of the sampling stations in the southeastern Beaufort Sea, including the Amundsen Gulf, during summer 2008

profiles (Tremblay et al. 2009; Table 1). Surface-tethered drifting particle interceptor traps were deployed at $100 \mathrm{~m}$ for 12-26 h, except at two stations (station CA16: $41 \mathrm{~h}$; station CA04: $8.2 \mathrm{~h}$ ). The trap array was attached to a radio beacon and an Argos buoy for short- and long-range location, respectively. We estimate that the difference between $Z_{\text {eu }}$ and trap deployment depth $\left(Z_{\text {trap }}\right)$ at some stations (see Table 1) could have induced underestimations $\left(Z_{\text {eu }}<Z_{\text {trap }}\right)$ or overestimations $\left(Z_{\text {eu }}>Z_{\text {trap }}\right)$ of POC sinking fluxes of 9 and $2 \%$ on average, respectively. Details on the particle interceptor traps and deployment procedures are given in Juul-Pedersen et al. (2008). Particle interceptor trap deployment and handling were carried out in accordance with JGOFS protocols (Knap et al. 1996) and recommendations of Gardner (2000). Prior to deployment, the traps were filled with seawater collected below $200 \mathrm{~m}$ and filtered onto $0.22-\mu \mathrm{m}$ polyvinyliden fluoride (PVDF)
Millipore Durapore membrane filters. Upon recovery, a clean lid was placed on each trap and the material collected was left to sediment for a period of $8 \mathrm{~h}$ at $4^{\circ} \mathrm{C}$ in the dark. After the sedimentation period, the supernatant was gently removed and the remaining sample was sieved through $450 \mu \mathrm{m}$ mesh in order to remove large swimmers (study wide, only one large swimmer was observed and removed). Particle interceptor trap samples from the same depth horizon were pooled together to obtain one sample for which the volume was measured prior to analysis.

Water column samples were collected at seven optical depths $(100,50,30,15,5,1$, and $0.2 \%$ of surface irradiance), at the depth of maximum chlorophyll fluorescence $\left(Z_{\mathrm{DCM}}\right)$ and at two aphotic depths between $Z_{\mathrm{eu}}$ and $100 \mathrm{~m}$ with a rosette sampler equipped with 121 Niskin-type bottles (OceanTest Equipment), an in situ fluorometer (SeaPoint model 2465), and a SBE-911 plus CTD probe (Sea-Bird Electronics, Inc.). Biochemical analyses were performed on the particle interceptor traps and water column samples as described below.

\section{Analyses}

\section{Particle interceptor traps}

For chlorophyll $a(\mathrm{chl} a)$ and phaeopigment determination, duplicate subsamples were filtered onto Whatman GF/F glass-fiber filters (nominal pore size of $0.7 \mu \mathrm{m}$; total biomass) and onto $5 \mu \mathrm{m}$ Poretics polycarbonate membrane filters (biomass of large cells, i.e., $>5 \mu \mathrm{m}$ ). After $24 \mathrm{~h}$ extraction in $90 \%$ acetone at $4^{\circ} \mathrm{C}$ in the dark, fluorescence was measured before and after acidification using a Turner Designs 10-AU fluorometer (Parsons et al. 1984),

Table 1 Characteristics of free-drifting particle interceptor trap moorings and of the water column $\left(Z_{\text {eu }}\right.$ : euphotic zone depth, $Z_{\text {mix }}$ : surface mixed layer depth), in the southeastern Beaufort Sea, during summer 2008

\begin{tabular}{|c|c|c|c|c|c|c|c|c|c|c|c|}
\hline \multirow[t]{2}{*}{ Station } & \multirow{2}{*}{$\begin{array}{l}\text { Deployment } \\
\text { date }\end{array}$} & \multirow{2}{*}{$\begin{array}{l}\text { Duration } \\
\text { (day) }\end{array}$} & \multicolumn{2}{|c|}{ Deployment } & \multicolumn{2}{|l|}{ Recovery } & \multirow{2}{*}{$\begin{array}{l}\text { Distance } \\
\text { travelled } \\
(\mathrm{km})\end{array}$} & \multirow{2}{*}{$\begin{array}{l}\text { Mean } \\
\text { speed } \\
\left(\mathrm{cm} \mathrm{s}^{-1}\right)\end{array}$} & \multirow{2}{*}{$\begin{array}{l}\text { Water } \\
\text { depth } \\
\text { (m) }\end{array}$} & \multirow{2}{*}{$\begin{array}{l}Z_{\mathrm{eu}} \\
(\mathrm{m})\end{array}$} & \multirow{2}{*}{$\begin{array}{l}Z_{\text {mix }} \\
(\mathrm{m})\end{array}$} \\
\hline & & & $\begin{array}{l}\text { Latitude } \\
\left({ }^{\circ} \mathrm{N}\right)\end{array}$ & $\begin{array}{l}\text { Longitude } \\
\left({ }^{\circ} \mathrm{W}\right)\end{array}$ & $\begin{array}{l}\text { Latitude } \\
\left({ }^{\circ} \mathrm{N}\right)\end{array}$ & $\begin{array}{l}\text { Longitude } \\
\left({ }^{\circ} \mathrm{W}\right)\end{array}$ & & & & & \\
\hline 1216 & 23 June & 0.50 & $70^{\circ} 37.2^{\prime}$ & $127^{\circ} 35.8^{\prime}$ & $70^{\circ} 33.0^{\prime}$ & $127^{\circ} 31.9^{\prime}$ & 7.9 & 18.3 & 173 & 58 & 9 \\
\hline 1208 & 28 June & 0.68 & $71^{\circ} 04.4^{\prime}$ & $126^{\circ} 04.8^{\prime}$ & $71^{\circ} 05.3^{\prime}$ & $126^{\circ} 16.6^{\prime}$ & 7.4 & 12.6 & 410 & 60 & 8 \\
\hline 421 & 30 June & 0.79 & $71^{\circ} 28.2^{\prime}$ & $133^{\circ} 55.6^{\prime}$ & $71^{\circ} 30.4^{\prime}$ & $133^{\circ} 38.6^{\prime}$ & 10.7 & 15.7 & 1184 & 78 & 8 \\
\hline 6006 & 03 July & 0.66 & $72^{\circ} 39.8^{\prime}$ & $128^{\circ} 22.1^{\prime}$ & $72^{\circ} 39.3^{\prime}$ & $128^{\circ} 20.8^{\prime}$ & 1.0 & 1.7 & 224 & 100 & 11 \\
\hline 410 & 08 July & 0.68 & $71^{\circ} 42.3^{\prime}$ & $126^{\circ} 30.4^{\prime}$ & $71^{\circ} 43.9^{\prime}$ & $126^{\circ} 18.9^{\prime}$ & 7.2 & 12.2 & 400 & 108 & 14 \\
\hline 416 & 09 July & 0.75 & $71^{\circ} 17.9^{\prime}$ & $127^{\circ} 76.5^{\prime}$ & $71^{\circ} 18.1^{\prime}$ & $127^{\circ} 46.7^{\prime}$ & 17.9 & 27.6 & 160 & 108 & 22 \\
\hline D34 & 13 July & 0.59 & $71^{\circ} 04.8^{\prime}$ & $121^{\circ} 49.9^{\prime}$ & $71^{\circ} 03.7^{\prime}$ & $122^{\circ} 00.1^{\prime}$ & 6.8 & 10.5 & 181 & 86 & 13 \\
\hline CA18 & 20 July & 0.76 & $70^{\circ} 40.5^{\prime}$ & $122^{\circ} 57.9^{\prime}$ & $70^{\circ} 42.9^{\prime}$ & $123^{\circ} 06.1^{\prime}$ & 6.6 & 10.0 & 584 & 84 & 12 \\
\hline CA16 & 22 July & 1.71 & $71^{\circ} 44.2^{\prime}$ & $126^{\circ} 29.8^{\prime}$ & $71^{\circ} 41.5^{\prime}$ & $126^{\circ} 26.8^{\prime}$ & 5.7 & 3.9 & 363 & 95 & 13 \\
\hline CA05 & 25 July & 1.09 & $71^{\circ} 19.2^{\prime}$ & $127^{\circ} 35.5^{\prime}$ & $71^{\circ} 15.1^{\prime}$ & $127^{\circ} 30.4^{\prime}$ & 8.0 & 8.5 & 207 & 80 & 9 \\
\hline CA08 & 26 July & 0.55 & $71^{\circ} 00.2^{\prime}$ & $126^{\circ} 02.6^{\prime}$ & $70^{\circ} 58.8^{\prime}$ & $126^{\circ} 05.5^{\prime}$ & 3.9 & 8.2 & 391 & 80 & 11 \\
\hline CA04 & 30 July & 0.34 & $71^{\circ} 04.3^{\prime}$ & $133^{\circ} 45.5^{\prime}$ & $71^{\circ} 01.1^{\prime}$ & $133^{\circ} 45.0^{\prime}$ & 5.6 & 19.1 & 292 & 70 & 18 \\
\hline
\end{tabular}


previously calibrated using pure chl $a$ extract from Anacystis nidulans (Sigma).

Duplicate subsamples were filtered onto pre-combusted $\left(450^{\circ} \mathrm{C}\right.$ for $\left.5 \mathrm{~h}\right)$ Whatman $\mathrm{GF} / \mathrm{F}$ filters for particulate carbon (PC) and nitrogen (PN) determination. The filters were dried at $60^{\circ} \mathrm{C}$ for $24 \mathrm{~h}$ aboard the ship and analyzed in the laboratory on a Costech ECS 4010 CHN analyzer without prior acidification of the sample. Recent studies in our study area showed that particulate organic carbon (POC) represents $>90 \%$ of PC concentrations in surface waters and particle interceptor traps (Juul-Pedersen et al. 2008; Forest et al. 2010). Therefore, we refer to POC concentrations throughout the manuscript. Carbon and nitrogen isotopic ratios of duplicate trap samples were determined on pre-combusted GF/F filters using an Isotope Ratio Mass Spectrometer (IRMS) Delta ${ }^{\text {Plus }}$ XP of Thermo Electron Co coupled to the CHN analyzer. The average coefficient of variation was 5\% for duplicate POC and PN measurements and $2 \%$ for duplicate carbon and nitrogen isotopic ratio measurements.

Triplicate subsamples were filtered on $47 \mathrm{~mm} 0.4 \mu \mathrm{m}$ Nuclepore polycarbonate membrane filters and stained with Alcian Blue for the analysis of exopolymeric substances (EPS). EPS, defined as $>0.4 \mu \mathrm{m}$ acidic exopolysaccharides, were measured colorimetrically (at $787 \mathrm{~nm}$ ) after a $2 \mathrm{~h}$ extraction in $80 \% \mathrm{H}_{2} \mathrm{SO}_{4}$ (Passow and Alldredge 1995). The average coefficient of variation of triplicate EPS measurements was 6\%. EPS concentrations were estimated as $\mu \mathrm{g}$ gum xanthan equivalent (Xeq) $1^{-1}$ and converted to carbon equivalents (EPS-C) according to Engel (2004).

Samples for protist cells and zooplankton fecal pellets were preserved with acidic Lugol's solution ( $0.4 \%$ final concentration) and buffered formaldehyde (1\% final concentration), respectively. Identification and enumeration of protist cells were performed under an inverted microscope (WILD Heerbrugg) equipped with phase contrast optics, according to Lund et al. (1958). For each sample, at least 400 cells were counted over a minimum of three transects. The abundance of protists was calculated according to the equation of Horner (2002). Thirty individual cells were measured to obtain average cell sizes of the dominant protist taxa. For the least abundant taxa, average cell sizes were obtained from the literature (Tomas 1997; BérardTherriault et al. 1999). Together, these taxa represented, on average $91 \%$ of total cell numbers. The biovolume of each taxon was estimated using the appropriate geometric equation (Hillebrand et al. 1999). Biovolumes were converted into protist carbon biomass (protist-C) using the factors of Menden-Deuer and Lessard (2000) for diatoms, dinoflagellates, and flagellates and of Putt and Stoecker (1989) for ciliates. Fecal pellets were also counted and measured using inverted microscopy. Two types of fecal pellets were identified by shape, cylindrical, and ellipsoidal, assumed to be calanoid copepod or appendicularian/ cyclopoid copepod feces, respectively. The length and width of complete and broken fecal pellets were measured, and the total biovolume of each type of pellets was calculated using the appropriate geometric equations. Biovolumes were then converted into fecal pellet carbon biomass (FPC), using a conversion factor of $0.057 \mathrm{mg} \mathrm{C} \mathrm{mm}^{-3}$ for cylindrical pellets and $0.029 \mathrm{mg} \mathrm{C} \mathrm{mm}^{-3}$ for ellipsoidal pellets (González and Smetacek 1994), as in Juul-Pedersen et al. (2010). These conversion factors are similar to those measured for copepods in Amundsen Gulf in June-July (i.e., $0.054 \mathrm{mg} \mathrm{C} \mathrm{mm}^{-3}$, Seuthe et al. 2007) and for appendicularians in northern Barents Sea in July (i.e., $0.025 \mathrm{mg} \mathrm{C} \mathrm{mm}^{-3}$, Wexels Riser et al. 2007).

\section{Water column}

Primary production rates were measured at the seven optical depths (including the depth of maximum chlorophyll fluorescence) using the ${ }^{14} \mathrm{C}$-assimilation method (Knap et al. 1996; Gosselin et al. 1997) with on deck in situ simulated incubations for $24 \mathrm{~h}$. As in Gosselin et al. (1997), particulate primary production rates were determined for small $(0.7-5 \mu \mathrm{m})$ and large $(>5 \mu \mathrm{m})$ phytoplankton cells. Concentrations of chl $a$ for small $(0.7-5 \mu \mathrm{m})$ and large $(>5 \mu \mathrm{m})$ phytoplankton cells were determined at all sampled depths, as described above. POC concentrations were determined at 3-4 depths (i.e., 50 and $15 \%$ of surface irradiance, $Z_{\mathrm{DCM}}$, and $100 \mathrm{~m}$ ), as described above. Rates and concentrations were integrated over $Z_{\mathrm{eu}}$ and the upper $100 \mathrm{~m}$ of the water column, respectively, using trapezoidal integration (Knap et al. 1996).

\section{Calculations and statistical analysis}

Sinking fluxes were calculated, for each variable, using the following equation (Juul-Pedersen et al. 2008):

$S=\left(C_{\text {trap }} \times V_{\text {trap }}\right) /\left(A_{\text {trap }} \times T_{\text {dep }}\right)$

where $\mathrm{S}\left(\mathrm{mg} \mathrm{m}^{-2} \mathrm{day}^{-1}\right)$ is the sinking flux of the variable, $C_{\text {trap }}\left(\mathrm{mg} \mathrm{m}^{-3}\right)$ is the concentration of the measured variable in the particle interceptor trap sample at $100 \mathrm{~m}, V_{\text {trap }}$ $\left(\mathrm{m}^{3}\right)$ is the volume of the trap sample, $A_{\text {trap }}\left(\mathrm{m}^{2}\right)$ is the trap surface area, and $T_{\text {dep }}$ (day) is the deployment time.

Daily loss rates $\left(\%\right.$ day $\left.^{-1}\right)$ were calculated using the following equation (Olli et al. 2002):

$D=S / C_{\text {int }} \times 100$

where $D\left(\%\right.$ day $\left.^{-1}\right)$ is the daily loss rate of variable, $S$ is the sinking flux $\left(\mathrm{mg} \mathrm{m}^{-2} \mathrm{day}^{-1}\right)$ of the variable estimated from Eq. 1, and $C_{\text {int }}\left(\mathrm{mg} \mathrm{m}^{-2}\right)$ is the integrated concentration of chl $a$ or POC in the $0-100 \mathrm{~m}$ stratum. The export 
ratio was calculated as the ratio of the POC sinking flux at $100 \mathrm{~m}$ to the total particulate phytoplankton production integrated over $Z_{\mathrm{eu}}$. This ratio is dimensionless.

Potential mesozooplankton ingestion rates $(I)$ were estimated from the FPC sinking flux $(E)$, assuming an assimilation efficiency (AE) of $70 \%$ (Carlotti et al. 2000) and using the following equation (Båmstedt et al. 2000):

$I=E /(1-\mathrm{AE})$

Mann-Whitney test was used to assess any significant difference between sampling periods (Zar 1999). Kendall's coefficient of rank correlation $(\tau)$ was used to determine relationships between two variables. Statistical analyses were carried out using JMP version 5 (SAS Institute).

\section{Results}

During summer 2008, POC sinking fluxes at $100 \mathrm{~m}$ ranged from $38 \mathrm{mg} \mathrm{C} \mathrm{m}^{-2}$ day $^{-1}$ at Stn CA05 in late July to $257 \mathrm{mg} \mathrm{C} \mathrm{m}^{-2}$ day $^{-1}$ at the Cape Bathurst Stn 1216 in late June/early July, with a mean of $93 \pm 56 \mathrm{mg} \mathrm{C}$ $\mathrm{m}^{-2}$ day $^{-1}$ for all stations visited $(n=12$, Fig. $2 \mathrm{a}, \mathrm{b}$, Table 2). There was no significant difference in POC sinking fluxes between late June/early July and late July (Mann-Whitney test, $P>0.05$ ).
Total pigments (i.e., chlorophyll $a+$ phaeopigments) sinking fluxes ranged from $0.4 \mathrm{mg} \mathrm{m}^{-2}$ day $^{-1}$ at Stn CA04 to $11 \mathrm{mg} \mathrm{m}^{-2}$ day $^{-1}$ at the Cape Bathurst Stn 1216, with a mean of $3.8 \pm 3.3 \mathrm{mg} \mathrm{m}^{-2}$ day $^{-1}$ (Fig. $2 \mathrm{c}$, d). Phaeopigments made up, on average, $76 \% \pm 6 \%$ of the total pigment sinking flux during the study. Sinking fluxes of total pigments, phaeopigments, and chl $a$ were significantly higher in late June/early July (mean of $5.6 \pm 3.2$, $4.1 \pm 2.2$, and $1.4 \pm 1.1 \mathrm{mg} \mathrm{m}^{-2} \mathrm{day}^{-1}$, respectively, $n=7$ ) than in late July (mean of $1.3 \pm 0.8,1.0 \pm 0.7$, and $0.3 \pm 0.2 \mathrm{mg} \mathrm{m}^{-2} \mathrm{day}^{-1}$, respectively, $n=5$ ) (MannWhitney tests, $P<0.05$ ).

Table 2 presents sinking fluxes of protist-C, FPC, and EPS-C, the contribution of protist- $\mathrm{C}$ and FPC to POC sinking flux at $100 \mathrm{~m}$, during summer 2008. The maximum sinking fluxes of protist-C, FPC, and EPS-C, as well as their maximum percent contribution to POC sinking fluxes, were observed in late June/early July (Table 2). Sinking fluxes of protist-C, FPC, and EPS-C and their percent contribution to POC sinking fluxes were not significantly different between the two sampling periods (Mann-Whitney tests, $P>0.05$ ). EPS-C sinking fluxes were strongly correlated with POC sinking fluxes $(\tau=0.82, P<0.01$; Fig. 3).

In late June/early July, diatoms dominated the protist sinking fluxes, in terms of cell abundance and carbon
Fig. 2 Spatial variations in sinking fluxes of (a,

b) particulate organic carbon (POC) and (c, d) pigments (chlorophyll $a$ and

phaeopigments) at $100 \mathrm{~m}$ in the study region during $(\mathbf{a}, \mathbf{c})$ late June/early July and $(\mathbf{b}, \mathbf{d})$ late July. Bars and vertical lines represent means and standard deviations for duplicate samples
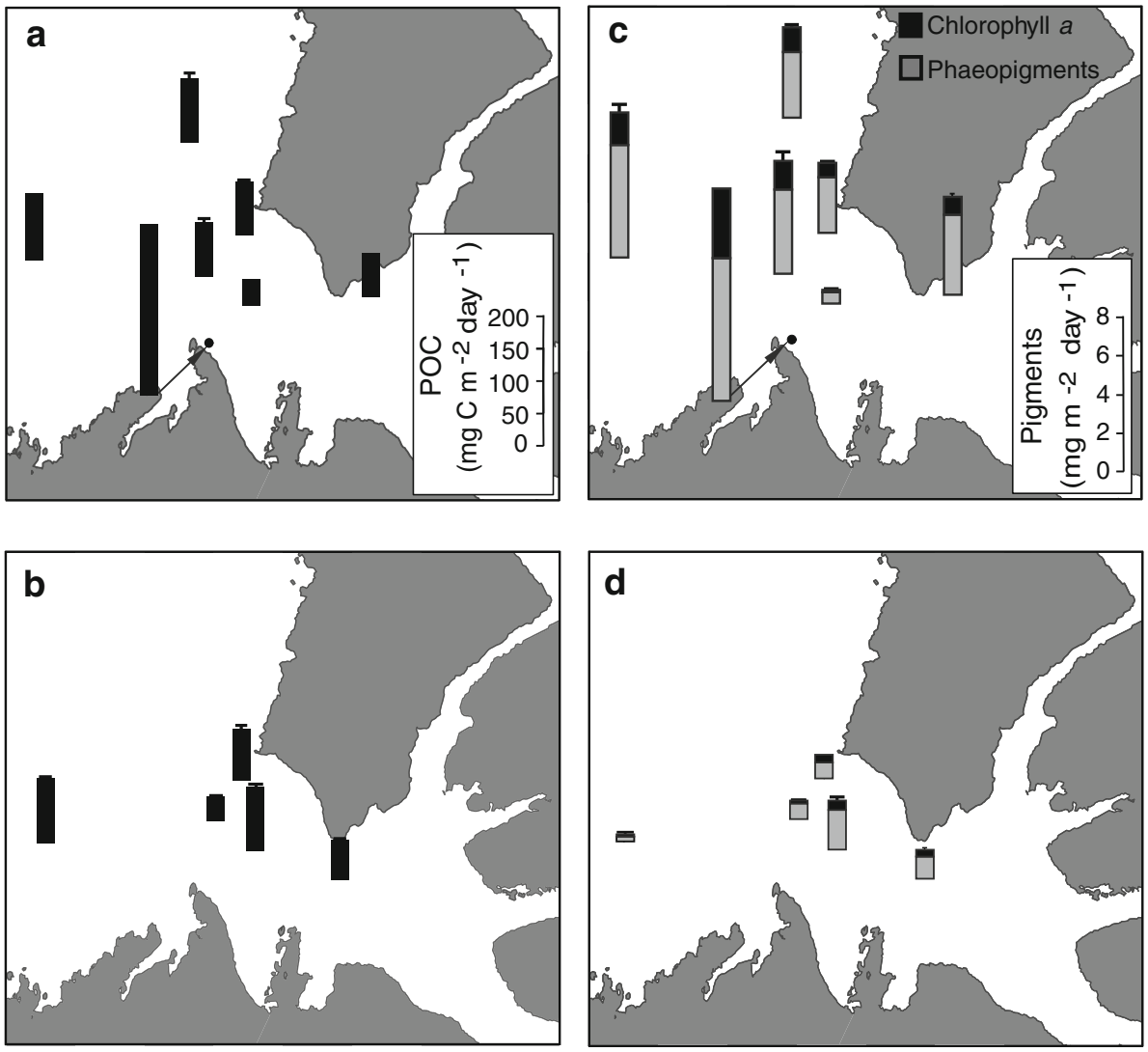
Table 2 Sinking fluxes of chlorophyll $a$ (chl $a$ ), particulate organic carbon (POC), protist carbon (protist-C), fecal pellet carbon (FPC), and exopolymeric substances carbon (EPS-C) at $100 \mathrm{~m}$, in the southeastern Beaufort Sea, during summer 2008

\begin{tabular}{|c|c|c|c|c|c|c|}
\hline \multirow[t]{2}{*}{ Period } & \multirow[t]{2}{*}{ Station } & \multicolumn{5}{|c|}{ Sinking flux $\left(\mathrm{mg} \mathrm{m}^{-2} \mathrm{day}^{-1}\right)$ or percent carbon contribution $(\%)$} \\
\hline & & Chl $a$ & POC & Protist-C & FPC & EPS-C \\
\hline \multirow[t]{7}{*}{ Late June/early July } & 1216 & 3.64 & 257 & $109(42.3)$ & $17.2(6.70)$ & $150 \pm 1.03$ \\
\hline & 1208 & $0.12 \pm 0.01$ & $41.9 \pm 0.47$ & $4.89(11.7)$ & $17.8(42.5)$ & nd \\
\hline & 421 & $1.70 \pm 0.17$ & 104 & $48.1(46.3)$ & $51.2(49.3)$ & $97.4 \pm 1.12$ \\
\hline & 6006 & $1.28 \pm 0.02$ & $98.4 \pm 9.26$ & $21.7(22.0)$ & $27.4(27.9)$ & $61.1 \pm 1.62$ \\
\hline & 410 & $0.75 \pm 0.02$ & $83.1 \pm 2.36$ & $15.0(18.0)$ & $25.6(30.9)$ & $34.5 \pm 1.35$ \\
\hline & 416 & $1.48 \pm 0.14$ & $84.2 \pm 5.72$ & $35.9(42.6)$ & $42.4(50.4)$ & $59.3 \pm 10.1$ \\
\hline & D34 & $0.93 \pm 0.02$ & 68.1 & $38.3(56.3)$ & $24.5(36.0)$ & $15.1 \pm 8.32$ \\
\hline \multirow[t]{5}{*}{ Late July } & CA18 & $0.36 \pm 0.07$ & $62.0 \pm 2.20$ & $23.6(38.1)$ & $23.5(37.9)$ & $33.1 \pm 1.19$ \\
\hline & CA16 & 0.40 & $80.0 \pm 4.90$ & $6.75(8.43)$ & $34.5(43.2)$ & $29.6 \pm 1.34$ \\
\hline & CA05 & $0.16 \pm 0.01$ & $38.3 \pm 1.29$ & $3.96(10.3)$ & $18.0(47.1)$ & 10.8 \\
\hline & CA08 & $0.49 \pm 0.01$ & $99.4 \pm 3.64$ & $23.9(24.0)$ & $39.8(40.1)$ & $33.4 \pm 2.63$ \\
\hline & CA04 & $0.11 \pm 0.01$ & $100 \pm 3.03$ & $12.3(12.3)$ & $43.8(43.7)$ & $86.2 \pm 1.52$ \\
\hline Late June/early July & & $1.41 \pm 1.11$ & $105 \pm 70.0$ & $38.9 \pm 34.2(34.2 \pm 16.8)$ & $29.4 \pm 12.7(34.8 \pm 15.1)$ & $69.6 \pm 48.2$ \\
\hline Late July & & $0.30 \pm 0.16$ & $76.0 \pm 26.2$ & $14.1 \pm 9.31(18.6 \pm 12.5)$ & $31.9 \pm 10.9(42.4 \pm 3.53)$ & $38.6 \pm 28.2$ \\
\hline All periods & & $0.95 \pm 1.00$ & $93.0 \pm 56.1$ & $28.6 \pm 28.9(27.7 \pm 16.6)$ & $30.5 \pm 11.5(38.0 \pm 12.0)$ & $55.5 \pm 41.7$ \\
\hline
\end{tabular}

Numbers in parentheses indicate the percent contribution of protist-C and FPC to total POC sinking flux. Values are mean \pm SD when applicable ( $n=2$ for chl $a$ and POC sinking fluxes and $n=3$ for EPS-C sinking flux). $n d$ not determined

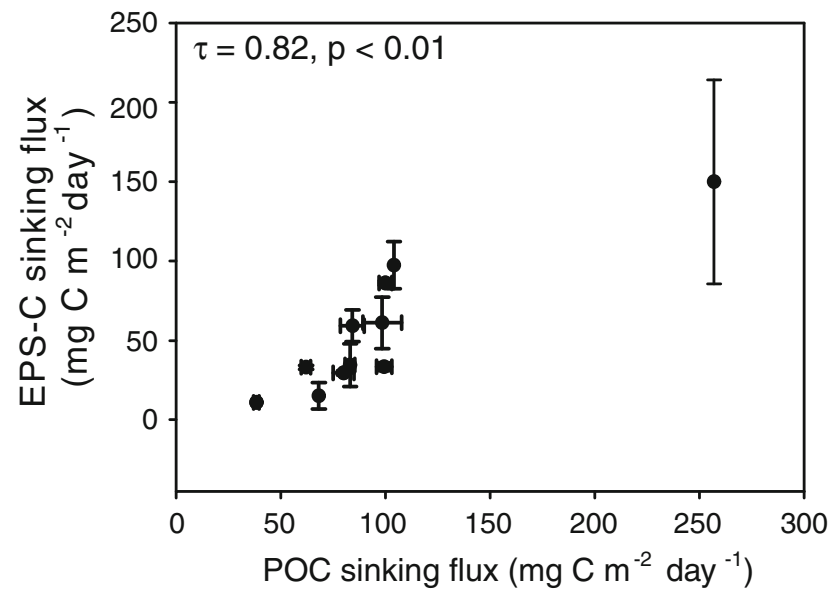

Fig. 3 Relationship between exopolymeric substance carbon (EPSC) and particulate organic carbon (POC) sinking fluxes at $100 \mathrm{~m}$ in the study region during summer 2008. Symbols and error bars indicate means and standard deviations for $n=2$ and 3 , respectively

biomass, throughout the sampling area, except at Stn 1208 where both fluxes were dominated by flagellated cells (i.e., flagellates + dinoflagellates) (Fig. 4a, b). In late July, the cell sinking flux was dominated by diatoms at Stns CA16 and CA18 and by flagellated cells at the other stations (Fig. 4a). In terms of protist-C, the sinking flux was dominated by diatoms throughout the sampling area, except at Stn CA04 where ciliates were the main sinking protist group (Fig. 4b). The contribution of diatoms to total cell sinking fluxes decreased significantly from late June/ early July $(79 \% \pm 21 \%)$ to late July $(44 \% \pm 14 \%)$, whereas the contribution of flagellates increased from late June/early July $(18 \% \pm 18 \%)$ to late July $(46 \% \pm 13 \%)$ (Mann-Whitney tests, $P<0.05$; Fig. 4a).

The flagellate and dinoflagellate assemblages in the particle interceptor traps were mainly composed (cell abundance and carbon biomass) of cryptophytes and unidentified Gymnodinium/Gyrodinium spp. (21-50 $\mu \mathrm{m})$ and Protoperidinium ovatum, respectively. The pennate diatom Fragilariopsis cylindrus and centric diatoms of the genus Chaetoceros numerically dominated the diatom community at 50 and $17 \%$ of the stations, respectively (Fig. 5a). The other stations were composed of a mixed assemblage of diatom species (Fig. 5a). The sinking fluxes of intact diatoms and diatom frustules were significantly higher in late June/early July than in late July (MannWhitney tests, $P<0.05$; Fig. 5b). Spores were observed at all stations, with sinking fluxes ranging from $1 \times 10^{6}$ to $51 \times 10^{6}$ cells $\mathrm{m}^{-2}$ day $^{-1}$ (Fig. 5b).

Figure 6 presents the contributions of three size classes of cylindrical fecal pellets (based on width: $\leq 100,100-120$, and $>120 \mu \mathrm{m}$ ) (Fig. 6a) and of cylindrical and elliptical fecal pellets (Fig. 6b) to total FPC sinking fluxes, at $100 \mathrm{~m}$. The mean contribution of the three fecal pellet size classes $(\leq 100,100-120$, and $>120 \mu \mathrm{m})$ to total FPC sinking fluxes were $19 \% \pm 16 \%, 23 \% \pm 12 \%$, and $57 \% \pm 20 \%$, respectively $(n=12)$. At all stations, except $\operatorname{Stn} 1216$, fecal pellets $>100 \mu \mathrm{m}$ (i.e., $100-120$ and $>120 \mu \mathrm{m}$ ) dominated the FPC in the sinking material, with percent 

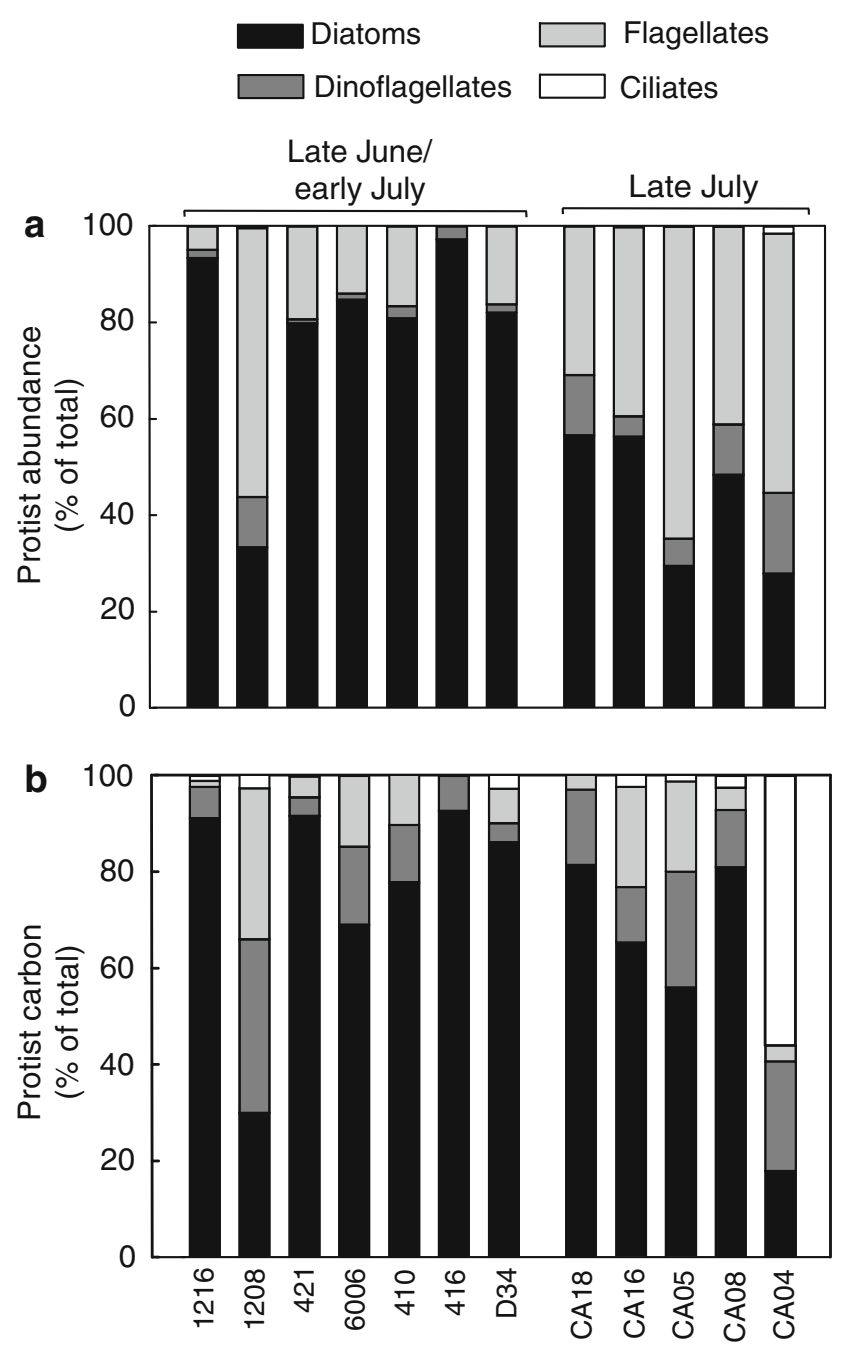

Fig. 4 Percent contribution of different protist groups in terms of $\mathbf{a}$ total abundance and $\mathbf{b}$ total carbon biomass in the sinking cells collected at $100 \mathrm{~m}$ in the study region during summer 2008. Empty cells not included in these estimates

contributions ranging from 68 to $94 \%$ (Fig. 6a). When excluding Stn 1216, there was a significant increase in the percent contribution of fecal pellets $(\leq 100 \mu \mathrm{m}$ to FPC) from late June/early July to late July (from $10 \% \pm 4 \%$ to $22 \% \pm 6 \%, n=11$, Mann-Whitney test, $P<0.05)$. The contribution of other fecal pellet size classes to FPC sinking fluxes did not vary significantly between the two periods (Mann-Whitney tests, $P>0.05$ ). From late June/early July to late July, the percent contribution of cylindrical fecal pellets to FPC sinking fluxes increased significantly, from $61 \% \pm 23 \%$ to $95 \% \pm 4 \%(n=11$, Mann-Whitney test, $P<0.05$; Fig. 6b). Concomitantly, a significant decrease in the percent contribution of elliptical pellets to the FPC sinking flux (from $39 \% \pm 23 \%$ to $5 \% \pm 4 \%$; MannWhitney test, $P<0.05$; Fig. 6 b) was observed. Over the study period, broken fecal pellets contributed, on average,

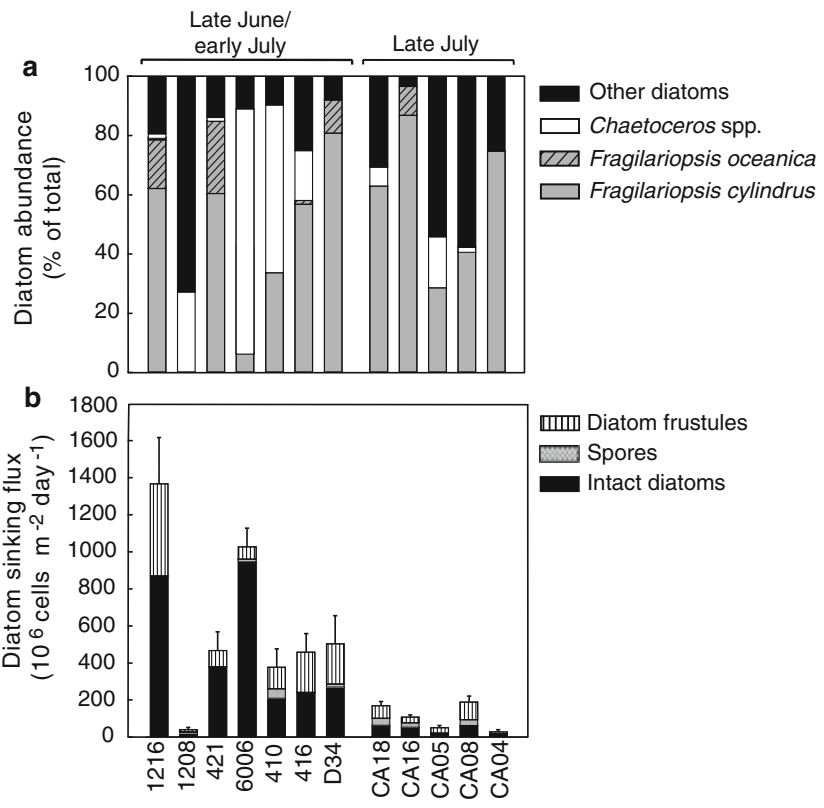

Fig. 5 a Percent contribution of dominant diatom taxa to total diatom number in the sinking material and $\mathbf{b}$ sinking flux of intact diatoms, spores, and empty diatom frustules, at $100 \mathrm{~m}$ in the study region during summer 2008. In a, empty cells were not included in these estimates. In b, bars and vertical lines represent means and standard deviations for total cell abundances
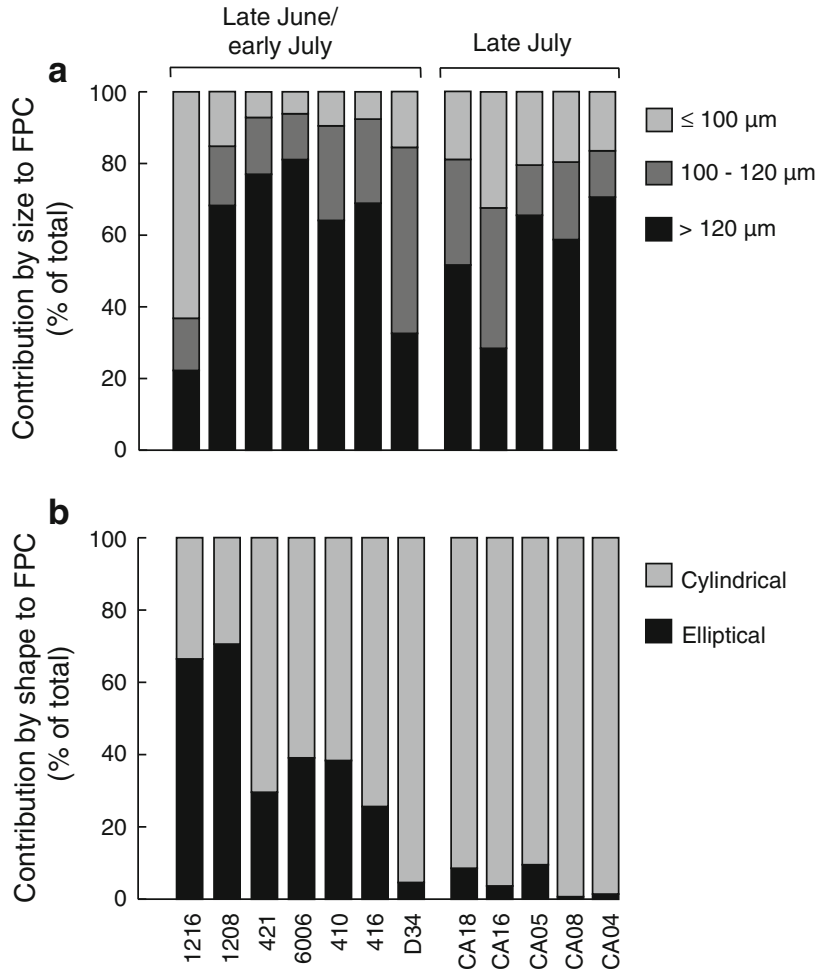

Fig. 6 Percent contribution of fecal pellets to total fecal pellet carbon (FPC) in the sinking material for a three size classes of fecal pellets (based on width, $\leq 100,100-120$, and $>120 \mu \mathrm{m}$ ) and $\mathbf{b}$ cylindrical and elliptical fecal pellets at $100 \mathrm{~m}$ in the study region during summer 2008 
Table 3 Primary production and chlorophyll $a$ (chl $a$ ) biomass integrated over the euphotic zone, daily loss rates of chl $a$, and particulate organic carbon (POC) at $100 \mathrm{~m}$ and particulate primary

\begin{tabular}{|c|c|c|c|c|c|c|c|c|}
\hline \multirow[t]{2}{*}{ Period } & \multirow[t]{2}{*}{ Station } & \multicolumn{2}{|l|}{ Primary production } & \multicolumn{2}{|c|}{ Chl $a$ biomass } & \multicolumn{2}{|c|}{ Daily loss rate } & \multirow[t]{2}{*}{ Export ratio } \\
\hline & & $\begin{array}{l}\text { Total } \\
\left(\mathrm{mg} \mathrm{C} \mathrm{m}^{-2} \text { day }^{-1}\right)\end{array}$ & $\begin{array}{l}\text { Large cells } \\
(>5 \mu \mathrm{m})(\%)\end{array}$ & $\begin{array}{l}\text { Total } \\
\left(\mathrm{mg} \mathrm{m}^{-2}\right)\end{array}$ & $\begin{array}{l}\text { Large cells } \\
(>5 \mu \mathrm{m})(\%)\end{array}$ & $\begin{array}{l}\text { Chl } a \\
\left(\% \text { day }^{-1}\right)\end{array}$ & $\begin{array}{l}\text { POC } \\
\left(\% \text { day }^{-1}\right)\end{array}$ & \\
\hline \multirow[t]{7}{*}{ Late June/early July } & 1216 & nd & nd & 50.5 & 91.3 & 4.6 & 2.5 & nd \\
\hline & 1208 & $926 \pm 22.6$ & 40.2 & $49.3 \pm 0.80$ & 31.9 & $0.2 \pm 1.2$ & 0.4 & 0.05 \\
\hline & 421 & $178 \pm 2.81$ & 77.3 & $68.8 \pm 3.51$ & 79.8 & $2.5 \pm 4.8$ & 1.1 & 0.58 \\
\hline & 6006 & $874 \pm 131$ & 79.6 & $66.9 \pm 3.67$ & 76.5 & $1.9 \pm 0.5$ & 1.7 & 0.11 \\
\hline & 410 & $510 \pm 2.57$ & 77.3 & $80.7 \pm 4.51$ & 80.4 & $0.9 \pm 0.4$ & 2.0 & 0.16 \\
\hline & 416 & $456 \pm 40.5$ & 76.6 & $135 \pm 20.2$ & 63.4 & $1.1 \pm 0.7$ & 0.9 & 0.18 \\
\hline & D34 & nd & nd & $291 \pm 68.8$ & 68.0 & $0.3 \pm 0.03$ & nd & nd \\
\hline \multirow[t]{5}{*}{ Late July } & CA18 & nd & nd & $104 \pm 2.96$ & 73.1 & $0.3 \pm 2.4$ & 0.5 & nd \\
\hline & CA16 & $105 \pm 6.71$ & 85.5 & $16.4 \pm 0.10$ & 90.8 & 2.4 & 1.9 & $0.76^{*}$ \\
\hline & CA05 & $454 \pm 26.1$ & 74.7 & $22.0 \pm 0.27$ & 27.1 & $0.7 \pm 3.7$ & 0.5 & 0.08 \\
\hline & CA08 & nd & nd & nd & nd & nd & nd & nd \\
\hline & CA04 & nd & nd & nd & nd & nd & nd & nd \\
\hline Late June/early July & & $589 \pm 311$ & $70.2 \pm 19.1$ & $106 \pm 86.5$ & $70.2 \pm 19.1$ & $1.6 \pm 1.5$ & $1.4 \pm 0.8$ & $0.22 \pm 0.21$ \\
\hline Late July & & $279 \pm 247$ & $80.1 \pm 7.64$ & $47.5 \pm 49.0$ & $63.7 \pm 32.9$ & $1.0 \pm 1.0$ & $1.0 \pm 0.8$ & $0.42 \pm 0.48$ \\
\hline All periods & & $500 \pm 312$ & $73.0 \pm 15.0$ & $88.5 \pm 79.5$ & $68.2 \pm 22.2$ & $1.4 \pm 1.4$ & $1.3 \pm 0.8$ & $0.27 \pm 0.28$ \\
\hline
\end{tabular}

Integrated or mean values $\pm \mathrm{SD}$ when applicable. $n d$ not determined

* May be due to allochthonous input (see text)

$90 \% \pm 8 \%(n=12)$ of the total number of sinking fecal pellets (data not shown).

Table 3 presents phytoplankton production and chl $a$ biomass integrated over the euphotic zone, together with daily loss rates of POC and chl $a$, and export ratios at $100 \mathrm{~m}$. Primary production and chl $a$ biomass varied between $105 \mathrm{mg} \mathrm{C} \mathrm{m}^{-2} \mathrm{day}^{-1}$ at Stn CA16 and $926 \mathrm{mg} \mathrm{C} \mathrm{m}^{-2}$ day $^{-1}$ at Stn 1208 and between $16 \mathrm{mg} \mathrm{m}^{-2}$ at Stn CA16 and $291 \mathrm{mg} \mathrm{m}^{-2}$ at the coastal Stn D34, respectively. Primary production and chl $a$ biomass were generally dominated by large $(>5 \mu \mathrm{m})$ phytoplankton cells $(73 \% \pm 15 \%$ and $68 \% \pm 22 \%$, respectively). Daily loss rates of POC and chl $a$ through sinking ranged from 0.4 to $2.5 \% \mathrm{day}^{-1}$ and 0.2 to $4.6 \% \mathrm{day}^{-1}$, respectively. Export ratios varied between 0.05 at Stn 1208 and 0.76 at Stn CA16. There was no significant difference between late June/early July and late July for any of these variables (Mann-Whitney tests, $P>0.05$ ). POC and EPS-C sinking fluxes at $100 \mathrm{~m}$ were significantly correlated with daily loss rates of chl $a(\tau=0.67, P<0.05$ and $\tau=0.59$, $P<0.05$, respectively).

Figure 7 shows stable isotopic signatures $\left(\delta^{13} \mathrm{C}\right.$ and $\left.\delta^{15} \mathrm{~N}\right)$ and particulate organic carbon/nitrogen $(\mathrm{C}: \mathrm{N})$ molar ratios of the material in the short-term particles interceptor traps at $100 \mathrm{~m}$ (June/July) in our sampling area. The isotopic signatures $\left(\delta^{13} \mathrm{C}\right.$ and $\left.\delta^{15} \mathrm{~N}\right)$ of the sinking material production exported through sinking (export ratio) in the southeastern Beaufort Sea, during summer 2008 

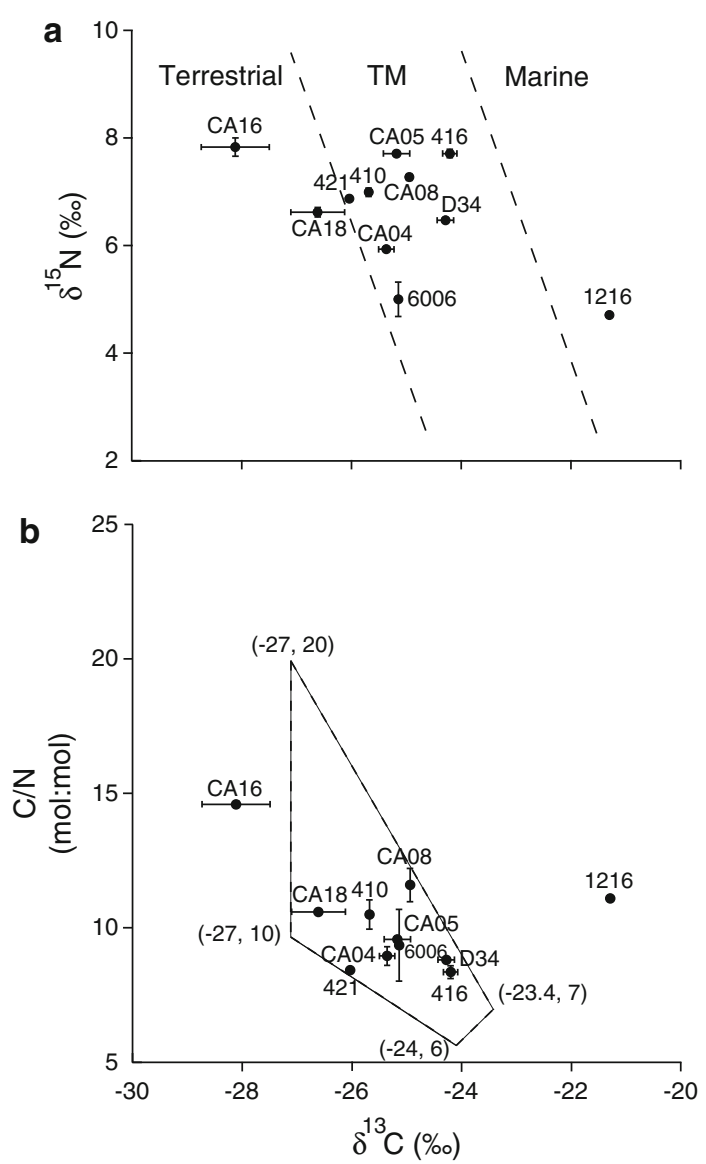

Fig. 7 Compositional signatures of the sinking material at $100 \mathrm{~m}$ in the study region during summer 2008. a Scatter plot of $\delta^{15} \mathrm{~N}$ versus $\delta^{13} \mathrm{C}$ signatures. Dashed lines represent Parsons' delineating lines (Parsons et al. 1989) for terrestrial (T) and marine (M) origin. TM represents an area of mixing between terrestrial and marine origin. b Scatter plot of $\mathrm{C}: \mathrm{N}$ ratios versus $\delta^{13} \mathrm{C}$ signature. Dashed lines delineate terrestrial and marine organic carbon. Approximate organic composition shown assumes a marine end-member of $\delta^{13} \mathrm{C}=-23.4$ to $-24 \%$, $\mathrm{C}: \mathrm{N}=6-7$, and a terrigenous organic carbon end-member of $\delta^{13} \mathrm{C}=-27 \%$ and $\mathrm{C}: \mathrm{N}=10-20$ (Macdonald et al. 2004). Error bars represent standard deviations of the mean for duplicate samples

the southeastern Beaufort Sea was recently (2002-2004) characterized during the Canadian Arctic Shelf Exchange Study (CASES). In 2004, sea ice started to retreat in early June to early August and the late June phytoplankton bloom was associated with high sinking fluxes of autochtonous POC (Forest et al. 2007). In 2008, the study region was covered by sea ice until mid-May. During this study, we revisited stations, which had previously been characterized (Juul-Pedersen et al. 2010), allowing for a comparative approach. The POC sinking flux at Stn CA04 (100 $\mathrm{mg} \mathrm{C} \mathrm{m}^{-2}$ day $^{-1}$; Fig. 2, Table 2) on the Mackenzie slope in late July (this study) was comparable to that measured at the end of June 2004 (Stn 708, ca. $100 \mathrm{mg} \mathrm{C} \mathrm{m}{ }^{-2}$ day $^{-1}$; Juul-Pedersen et al. 2010; Table 4). The POC sinking flux at Stn $1216\left(257 \mathrm{mg} \mathrm{C} \mathrm{m}^{-2}\right.$ day $^{-1}$;
Fig. 2, Table 2) was almost three times higher than that measured in summer 2004 (Stn 303, ca. $90 \mathrm{mg} \mathrm{C} \mathrm{m}^{-2}$ day $^{-1}$; Juul-Pedersen et al. 2010; Table 4).

On the one hand, the POC sinking fluxes measured during summer 2008 in the southeastern Beaufort Sea (this study) were relatively low compared to other productive Arctic shelves, ranging from 38 to $104 \mathrm{mg} \mathrm{C} \mathrm{m}^{-2}$ day $^{-1}$, except for Stn $1216\left(257 \mathrm{mg} \mathrm{C} \mathrm{m}^{-2}\right.$ day $^{-1}$; Fig. 2a, Tables 2 and 4). Excluding this station, the POC sinking fluxes measured in 2008 were similar to those in summer 2004 (see Juul-Pedersen et al. 2010; Mann-Whitney test, $P>0.05$; Table 4). The POC sinking fluxes in summer 2008 were lower than summer POC sinking fluxes estimated from short-term particle interceptor traps in the Barents Sea (58-720 mg C m ${ }^{-2}$ day $^{-1}$ at $90 \mathrm{~m}$; Reigstad et al. 2008), the Chukchi Sea (129-442 $\mathrm{mg} \mathrm{C} \mathrm{m}^{-2}$ day $^{-1}$ between 30 and $100 \mathrm{~m}$; Lalande et al. 2007), and northern Baffin Bay (142-554 $\mathrm{mg} \mathrm{C} \mathrm{m}^{-2}$ day $^{-1}$ between 50 and $150 \mathrm{~m}$; Caron et al. 2004).

On the other hand, primary production was ca. 3-5 times higher in 2008 (mean $500 \pm 312 \mathrm{mg} \mathrm{C} \mathrm{m}^{-2}$ day $^{-1}$; Table 3) than in summer 2004 (mean $162 \mathrm{mg} \mathrm{C} \mathrm{m}^{-2}$ day $^{-1}$; Juul-Pedersen et al. 2010). Primary production was also dominated by large cells during our study $(73 \% \pm$ $15 \%$; Table 3), whereas it was dominated by small cells in summer 2004 (>70\%; Gosselin et al. 2008). Upwelling events in spring-summer 2008 (Mundy et al. 2009; JeanÉric Tremblay, Laval University, pers. comm.) and a rapid decrease in ice extent in early May, ca. one month earlier than usual (Forest et al. 2011b) contributed to the observed increase in primary production in the Canadian Beaufort Sea in 2008. Daily primary production values in summer 2008 were comparable to mean summer values in the Chukchi Sea (458 mg C m ${ }^{-2}$ day $^{-1}$; Kirchman et al. 2009) and in the Barents Sea $\left(466 \mathrm{mg} \mathrm{C} \mathrm{m}^{-2}\right.$ day $^{-1}$; Hodal and Kristiansen 2008), but lower than those in northern Baffin Bay (2468 and $907 \mathrm{mg} \mathrm{C} \mathrm{m}^{-2}$ day $^{-1}$ in June and July 1998, respectively; Klein et al. 2002). In addition, suspended chl $a$ biomass in the euphotic zone appeared to be higher during our study than in summer 2004 (mean $88 \pm 79$ versus $18.8 \pm 8.9 \mathrm{mg}$ chl $a \mathrm{~m}^{-2}$; Brugel 2009) and large cells $(>5 \mu \mathrm{m})$ dominated the chl $a$ biomass during our study (mean $68 \% \pm 22 \%$; Table 3 ), except in the central Amundsen Gulf (Stn 1208) and at Stn CA05 (Table 3). This dominance contrasts with summer 2004 when large cells made up only $32 \% \pm 16 \%(n=21)$ of the total phytoplankton biomass throughout the study area (Brugel 2009).

Despite a high primary production, chl $a$ biomass, and a phytoplankton size structure based on the production and biomass of large cells in summer 2008 relative to summer 2004, POC sinking fluxes were comparable during both years (except for Stn 1216, see below). The low daily loss 
Table 4 Particulate organic carbon (POC) sinking export from short-term and long-term sediment traps on Arctic shelves

\begin{tabular}{lllllll}
\hline Method & $\begin{array}{l}\text { Depth } \\
(\mathrm{m})\end{array}$ & $\begin{array}{l}\text { POC } \\
\left(\mathrm{mg} \mathrm{C} \mathrm{m} \mathrm{day}^{-1}\right)\end{array}$ & Region (station \#) & Year & Month & Reference \\
\hline $\begin{array}{c}\text { Short-term } \\
\text { drifting }\end{array}$ & 100 & $38-257$ & Southeastern Beaufort Sea & 2008 & June-July & This study \\
$\begin{array}{c}\text { Short-term } \\
\text { drifting }\end{array}$ & 50 & 90 & $\begin{array}{l}\text { Southeastern Beaufort Sea } \\
(303=1216)\end{array}$ & 2004 & June & Juul-Pedersen et al. (2010) \\
$\begin{array}{c}\text { Short-term } \\
\text { drifting }\end{array}$ & 50 & 100 & Mackenzie slope (708 = CA04) & 2004 & June & Juul-Pedersen et al. (2010) \\
$\begin{array}{c}\text { Long-term } \\
\text { anchored }\end{array}$ & 118 & $<30$ & Canadian Beaufort Shelf (CA05) & 1987 & June-August & O'Brien et al. (2006) \\
$\begin{array}{c}\text { Long-term } \\
\text { anchored }\end{array}$ & 125 & $<15$ & Mackenzie slope (CA04) & 1987 & June-August & O'Brien et al. (2006) \\
$\begin{array}{c}\text { Long-term } \\
\text { anchored }\end{array}$ & 100 & $<75$ & Amundsen Gulf (CA08) & 2005,2006 & September- & Forest et al. (2010) \\
$\begin{array}{c}\text { Short-term } \\
\text { drifting }\end{array}$ & 90 & $58-720$ & Barents Sea & 2003,2004, & July & Reigstad et al. (2008) \\
$\begin{array}{c}\text { Short-term } \\
\text { drifting }\end{array}$ & 100 & $129-442$ & Chukchi Sea & 2005 & July-August & Lalande et al. (2007) \\
$\begin{array}{c}\text { Short-term } \\
\text { drifting }\end{array}$ & 100 & $142-554$ & Northern Baffin Bay & $1998-1999$ & June-August & Caron et al. (2004) \\
$\begin{array}{c}\text { Long-term } \\
\text { anchored }\end{array}$ & 175 & 250 & Northern Laptev Sea & 2007 & July & Lalande et al. (2009a) \\
\hline
\end{tabular}

rates of chl $a$ and POC in summer $2008\left(<5 \%\right.$ day $^{-1}$; Table 3) were similar to those in summer 2004 $\left(<4 \%\right.$ day $^{-1}$; Juul-Pedersen et al. 2010), indicating little transfer of suspended biomass to the benthos but rather channeling toward the pelagic food web. These results are in agreement with observations of a high biomass of copepods, dominated by the large calanoid species $C$. hyperboreus, C. glacialis, and M. longa, in the Amundsen Gulf in summer 2008 (Forest et al. 2011b). Consistent with these observations, we found (except for Stn 1216, see below) a high percent contribution of cylindrical fecal pellets and of fecal pellets $>100 \mu \mathrm{m}$ to the total FPC sinking flux (Fig. 6). The FPC sinking fluxes in the southeastern Beaufort Sea during summer 2008 (range: 17-51 $\mathrm{mg} \mathrm{C} \mathrm{m}^{-2} \mathrm{day}^{-1}$ ), and their contribution to POC sinking fluxes (range: 7-50\%) were similar to those reported for summer 2004 (ranges: 2.4-84 $\mathrm{mg} \mathrm{C} \mathrm{m}^{-2}$ day $^{-1}$ and 10-54\%; Juul-Pedersen et al. 2010). In addition, the percent FPC sinking flux explained by cylindrical pellets $(81 \% \pm 16 \%)$ was in close agreement with that observed in the Amundsen Gulf during summer 2004 (JuulPedersen et al. 2010). Our results show that, regardless of the high copepod biomass in summer 2008 (from 5 to $12 \mathrm{~g} \mathrm{C} \mathrm{m}^{-2}$; Forest et al. 2011a) compared to early fall 2002 and over 2003-2004 ( $\leq 4 \mathrm{~g} \mathrm{C} \mathrm{m}^{-2}$; Darnis et al. 2008; Forest et al. 2008), the FPC sinking fluxes were low and comparable to those in summer 2004. This indicates that high recycling took place in the water column during summer 2008. Microscopic observation of the fecal pellets collected in the sinking material supports these findings as $90 \%$ of the pellets were broken and many were in an advanced state of degradation.

Potential ingestion rates ranged from 59 to $171 \mathrm{mg} \mathrm{C} \mathrm{m}^{-2}$ day $^{-1}$ (Stns 1216 and 421, respectively). These ingestion rates could represent underestimations due to potential coprophagy/coprorhexy, as these processes can strongly reduce the vertical export of fecal pellets (Wexels Riser et al. 2002; Olli et al. 2007). These estimates indicate that the mesozooplankton could have ingested between $6 \%$ (Stn 1208) and 96\% (Stn 421) of the daily primary production during summer 2008, with a regional mean of $29 \% \pm 34 \%$ (data not shown). Unfortunately, these estimates cover only stations where primary production was measured and exclude Stn CA16 for reasons explained in the next Section. We can further estimate, based on the difference between the export ratio (ranging from 5 to $58 \%$; mean: $19 \% \pm 20 \%, n=6$ ) and the percent production grazed by mesozooplankton (mean: $29 \% \pm 17 \%$, $n=6)$, that, on average, $51 \% \pm 11 \%(n=7)$ of the primary production would have been recycled or channeled through the microbial food web. Since, on average, $80 \% \pm 20 \%(n=6)$ of the primary production in the euphotic zone would have been grazed by zooplankton (mainly large copepods) and recycled before reaching $100 \mathrm{~m}$, only a small fraction of that primary production was readily available for export to the depth. Accordingly, 
Forest et al. (2011b) estimated that 3\% of the primary production in the central Amundsen Gulf was exported to the benthos, during spring-summer 2008. Overall, our results highlight the central role of grazing and recycling processes (see also Kellogg et al. 2011) in the southeastern Beaufort Sea during the highly productive summer 2008.

\section{Sedimentation of phytoplankton-derived material}

We observed the same dominant species and a similar seasonal trend in the sinking protist assemblage in summer 2008 as in summer 2004 (Juul-Pedersen et al. 2010). However, the contribution of algal cells to POC sinking fluxes was more than twice that observed in summer 2004 (34.2 and $18.6 \%$ of POC sinking fluxes in late June/early July and late July, respectively; Table 2; 11.7 and $7.6 \%$ of POC sinking fluxes in June and July/August 2004, respectively; Juul-Pedersen et al. 2010). The contribution of algal cells and EPS to the sinking fluxes of organic material (Table 2) and the low abundance of empty frustules (Fig. 5) indicated the presence of fresh algal material sinking at $100 \mathrm{~m}$ in the southeastern Beaufort Sea, during summer 2008. To that effect, the flux of algal cells (Fig. 5) and protist carbon (Table 2) was almost one order of magnitude higher at Stn 1216 that at other stations, as further discussed below. The higher contribution of fresh algal material to the sinking POC in 2008 reflects the increase in primary production between summers 2004 and 2008; however, such increase had no apparent effect on the amount of sinking POC. Therefore, except at a station of exceptionally high production (Stn 1216), increases in primary production influenced the quality rather than the quantity of the sinking POC (see also Sampei et al. 2011).

During this study, concentrations of EPS-C contributed, on average, $53 \% \pm 23 \%(n=11)$ of the POC sinking fluxes (Table 2); therefore, these substances appeared to play a significant role in the sinking export of organic material. Phytoplankton and ice algae are known producers of EPS (Krembs et al. 2002; Passow 2002; Meiners et al. 2003; Riedel et al. 2006); yet, our results did not show any correlation between sinking fluxes of EPS-C and sinking fluxes of total protist carbon nor carbon from individual protist groups (diatoms, flagellates, dinoflagellates, ciliates; data not shown). This absence of correlation could reflect that sinking of EPS-C may be associated with aggregates (Verdugo et al. 2004; Wotton 2004) composed of diverse material, obscuring a direct correlation between EPS and protists. Indeed, we observed a significant correlation between EPS-C and POC sinking fluxes (Fig. 3), supporting the potential role of EPS as biological glue (Wotton 2004). While the role of EPS in the formation of aggregates is documented (Azetsu-Scott and Passow 2004; Verdugo et al. 2004; Wotton 2004), evidence of their contribution to the sinking flux of organic matter from the euphotic zone is presented here for the first time. Yet, our results on EPS-C sinking fluxes are somewhat ambiguous as the sum of the sinking fluxes of EPS-C, protist-C, and FPC in the sinking material was sometimes higher than the measured POC sinking fluxes (Table 2). There is a potential error associated with the use of carbon conversion factors that are either experimentally derived or estimated in different field conditions for chl $a$, FPC, protist-C, and EPS-C. Secondly, EPS was retained on filters with porosity of $0.4 \mu \mathrm{m}$, whereas POC was quantified on GF/F filters with nominal porosity of $0.7 \mu \mathrm{m}$. It is therefore possible that a significant proportion of the EPS-C was in the size range $0.4-0.7 \mu \mathrm{m}$ and would not have been accounted for in POC estimates. This agrees with previous results showing that a large fraction (i.e., $>50 \%$ ) of transparent exopolymeric substances can pass through GF/F or $0.6 \mu \mathrm{m}$ filters (Passow and Alldredge 1995; Engel and Passow 2001).

Despite the high contribution of EPS-C to POC sinking fluxes, EPS-C and POC sinking fluxes were relatively low during this study; therefore, EPS did not appear to accelerate the export of POC to the benthos. Instead, it is possible that the presence of EPS coatings on algal cells and their possible role in the formation of aggregates would have benefited the active microbial food web during summer 2008, in the southeastern Beaufort Sea. Indeed, EPS are known to facilitate bacterial attachment to particles (Parsmore and Costerton 2003) and can also be neutrally buoyant or even favor upward fluxes (Azetsu-Scott and Passow, 2004). On the Mackenzie shelf, Riedel et al. (2006, 2007) demonstrated that EPS may be an important substrate stimulating heterotrophic activity in newly formed sea ice.

Autochthonous versus allochthonous origin of the sinking material

Elemental (C:N) ratios and isotopic composition are often used to distinguish between marine and terrigenous organic matter in sediments and sinking matter (Macdonald et al. 2004). Typically, the C:N molar ratio of fresh marine organic material is ca. 6.6 (i.e., Redfield ratio, Redfield et al. 1963), whereas terrigenous organic matter has C:N molar ratios >15 (Stein and Macdonald 2004). A common approach to estimate the relative proportions of marine and terrigenous organic matter derives from the different isotopic signatures of organic matter from these two sources (i.e., marine and terrigenous end-members) (e.g., Stein and Macdonald 2004; Morata et al. 2008; Magen et al. 2010). A key challenge with this approach is to define end-members, as they vary widely depending on the region of study, as well as seasonally. For example, literature values for marine and terrestrial $\delta^{13} \mathrm{C}$ range from -18.0 to $-25.5 \%$ 
and -24.0 to $-28.0 \%$, respectively (Parsons et al. 1989; Naidu et al. 1993, 2000; Goericke and Frye 1994; Goñi et al. 2000; Macdonald et al. 2004; Amiel and Cochran 2008; Magen et al. 2010). While these ranges of values clearly illustrate a demarcation between marine and terrestrial material, it is apparent that even a slight change in the isotopic signature used for the end-member can have a disproportionate impact when estimating their relative contributions. For example, a decrease of $1 \%$ in the $\delta^{13} \mathrm{C}$ value of the marine end-member could increase the fraction of marine POC by ca. $10 \%$ (this study) to $20 \%$ (Amiel and Cochran 2008). In addition, in particle interceptor traps, other contributors such as copepod fecal pellets (depleted in $\delta^{13} \mathrm{C}$, Tamelander et al. 2006) or exopolymeric substances (enriched in $\delta^{13} \mathrm{C}$, Forest et al. 2007) also influence the isotopic signature of the material.

Given these limitations of the stable isotope approach and the environmental complexities of the study region, it is not surprising that isotopic signatures combined with $\mathrm{C}: \mathrm{N}$ ratios of the sinking material allowed the identification of only two stations of distinct hydrographic and/or biological characteristics (Stns 1216 and CA16; Fig. 7). Stn 1216, located north of Cape Bathurst, was the most enriched in $\delta^{13} \mathrm{C}$ (-21.3\%; Fig. 7), comparable to values deriving from sedimentation of fresh phytoplankton material during/after a bloom (Tremblay et al. 2006a). Indeed, this station had high chl $a$, protist-C, diatom cell, and EPS sinking fluxes and low FPC sinking flux (Figs. 2a, b, 5b, 6a; Tables 2 and 3). Bathymetric and oceanographic features at this station are conducive to upwelling of nutrientrich Pacific waters (Williams and Carmack 2008). There is evidence that such upwelling took place in mid-June 2008, increasing primary production by ca. threefold relative to 2004 (see Forest et al. 2011b). The sedimentation pattern observed at Stn 1216 is associated with the direct sinking of high phytoplankton biomass during the productive bloom induced by wind-driven upwelling as observed at the site in 2004 (Forest et al. 2011b; Sampei et al. 2011). These results show that increased primary production induced by wind-driven upwelling during a low ice year impacted the amount and composition of the material exported to depth on the Beaufort shelf.

Stn CA16, located at the shelf break in proximity of Banks Island (see Fig. 1), had a dominant terrigenous signature, possibly associated with the presence of sediments from coastal erosion off Banks Island. The presence of allochthonous material at Stn CA16 precludes a classic interpretation of variables such as the export ratio, which was highest at this station (0.76; Table 3 ) and would not reflect export sensu stricto. Coastal and seabed erosion have been identified as a source of sinking particles in the Beaufort Sea (O'Brien et al. 2006), and Banks Island can also be a source of suspended sediments that can become entrained in sea ice (Darby 2003) or captured in particle interceptor traps. There was no evidence of resuspension at station CA16. In addition, the potential impact of bacterial activity on the isotopic signature of the sinking material due to longer deployment time at this station is considered negligible. Storms have increased in frequency and intensity in the Beaufort Sea over the past decade (Yang et al. 2004; Barber et al. 2008), leading to increases in coastal erosion/horizontal advection near the coast (Hill et al. 1991; Dunton et al. 2006; Walker et al. 2008). We cannot evaluate if the terrigenous signature at Stn CA16 was of transient nature or if it reflects such broader changes in Arctic coastal dynamics. The absence of a terrigenous signature at Stn 410 located nearby does not support the latter. However, our results point to the relevance of particle interceptor traps to trace sources, and possibly transports, of material on Arctic shelves.

According to the compositional analysis based on the scatter plots (Fig. 7), all other stations visited would comprise a significant (from 20 to $90 \%$ ) proportion of terrigenous material. However, microscopic observation of the sinking material did not reveal the presence of terrigenous material, but showed an abundance of zooplankton fecal pellets and phytoplankton cells (on average, $66 \%$ of the POC sinking fluxes). Therefore, we conclude that the wide, and sometimes overlapping, ranges of isotopic values and $\mathrm{C}: \mathrm{N}$ ratios documented for different components of marine food webs in the Beaufort Sea (summarized in Table 5) challenges the interpretation of isotopic signatures in terms of terrestrial/marine components. This is even more exacerbated for particle interceptor traps as they collect a variety of primary- (e.g., phytoplankton cells, spores) and secondary- (e.g., fecal pellets, pteropod shells) produced material, together with allochthonous material from rivers (e.g., Juul-Pedersen et al. 2008) and coastal erosion in susceptible areas (e.g., Stn CA16). Such complexity is reflected in the wide range of stable isotope $\left(\delta^{13} \mathrm{C}\right.$ and $\delta^{15} \mathrm{~N} ;-28.11$ to $-21.29 \%$, +4.71 to $+7.83 \%$, respectively) and C:N ratios (8.4-14.6) during our study. Our results indicate that in the southeastern Beaufort Sea, isotopic signatures are effective at tracing the origin of the material when conditions are extreme, i.e., in samples with an abundance of sediment or fresh phytoplankton cells. This conclusion agrees with results from the North Water polynya, where the narrow isotopic signatures of an intense phytoplankton bloom were reflected in particle interceptor traps during its sedimentation (Tremblay et al. 2006b).

\section{Conclusions}

The combination of a rapid decrease in ice extent that occurred in early May, one month earlier than usual (Forest 


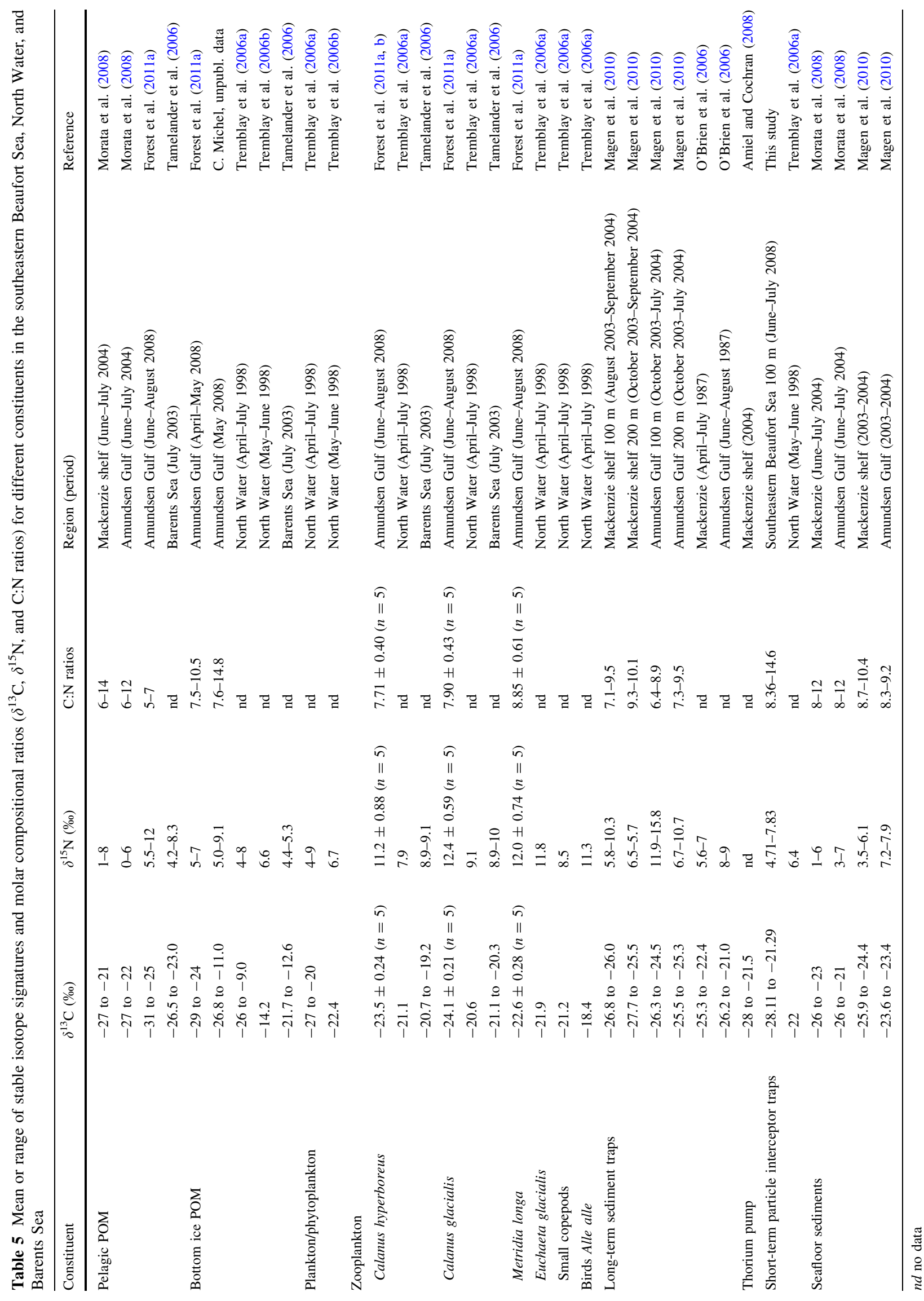


et al. 2011b), and upwelling events contributed to unprecedented high primary production (mainly large cells $>5 \mu \mathrm{m}$ ) in the southeastern Beaufort Sea in summer 2008 (see Forest et al. 2011b; Jean-Éric Tremblay, Laval University, pers. comm.). Yet, except for one upwelling station (Stn 1216), the POC sinking export in summer 2008 was comparable to that in summer 2004 and among the lowest documented for Arctic shelves. Bulk estimates indicate that $80 \% \pm 20 \%$ of the primary production was grazed by mesozooplankton or recycled in the upper $100 \mathrm{~m}$ and that only a small fraction of primary production was exported to depth during summer 2008. This finding points to a strong influence of pelagic processes in shaping the transfer of organic material within the marine food web of the southeastern Beaufort Sea. Our results also showed that increased primary production in summer 2008 impacted the composition of the sinking POC, as a higher proportion of phytoplankton cells was exported than in summer 2004. These findings suggest that future increases in primary production associated with changes in sea ice conditions may not increase the magnitude of POC sinking export but would likely alter the composition of sinking particles and increase the relative amount of fresh material available to benthic grazers.

Highest sinking fluxes of POC and phytoplankton were measured at productive upwelling Stn 1216 (Sampei et al. 2011). Given that the transfer of primary-produced biomass to pelagic grazers requires a tight coupling between biomass availability and the presence/activity of grazers (i.e., match/mismatch hypothesis), it is possible that such coupling may not be established in areas of high primary production relative to historical values, leading to significant sinking export of fresh particulate algal material at such productive sites. Interestingly, at one station influenced by coastal upwelling and at another influenced by erosion, the composition and magnitude of particulate sinking fluxes were markedly different from other stations visited during the study. These observations underscore the fundamental role played by mesoscale circulation patterns and hydrodynamic singularities for the sinking export of particulate organic material on Arctic shelves.

Acknowledgments The authors gratefully acknowledge the Canadian International Polar Year-Federal government program office, Natural Sciences and Engineering Research Council of Canada (IPYCFL and Discovery Grants to C.M. and M.G.), Fisheries and Oceans Canada, Institut des sciences de la mer de Rimouski (ISMER) and Québec-Océan through a grant from the Fonds québécois de la recherche sur la nature et les technologies for financial support. We are grateful to the CCGS Amundsen officers and crew for logistical support during the expedition. We also thank D.G. Barber, C.J. Mundy, G. Stern, A. Niemi, R. Laing, and S. Blondeau for support prior and during the expedition and R. Saint-Louis for $\mathrm{CHN}$ and isotopic analysis, M. Poulin for his invaluable help for the identification of protists, M. Ardyna and B. Philippe for primary production data, R. Laing for stable isotopes samples from bottom ice and surface water in May 2008, and G. Winkler, M. Reigstad, P. Wassmann, J. Deming, and 2 anonymous reviewers for their useful suggestions. This is a contribution to the research programs of the Circumpolar Flaw Lead (CFL) system study, the Freshwater Institute (Fisheries and Oceans Canada), ISMER and Québec-Océan.

Open Access This article is distributed under the terms of the Creative Commons Attribution Noncommercial License which permits any noncommercial use, distribution, and reproduction in any medium, provided the original author(s) and source are credited.

\section{References}

Amiel D, Cochran JK (2008) Terrestrial and marine POC fluxes derived from ${ }^{234} \mathrm{Th}$ distributions and $\delta^{13} \mathrm{C}$ measurements on the Mackenzie Shelf. J Geophys Res 113:C03S06. doi:10.1029/ 2007JC004260

Arrigo KR, van Dijken GL, Pabi S (2008) Impact of a shrinking Arctic ice cover on marine primary production. Geophys Res Lett 35:L19603. doi:10.1029/2008GL035028

Azetsu-Scott K, Passow U (2004) Ascending marine particles: Significance of transparent exopolymer particles (TEP) in the upper ocean. Limnol Oceanogr 49:741-748

Båmstedt U, Gifford DJ, Irigoien X, Atkinson A, Roman M (2000) Feeding. In: Harris RP, Wiebe PH, Lenz J, Skoldal HR, Huntley $M$ (eds) ICES zooplankton methodology manual. Academic Press, San Diego, pp 297-399

Barber DG, Lukovich JV, Keogak J, Baryluk S, Fortier L, Henry GHR (2008) The changing climate of the Arctic. Arctic 61(suppl 1):7-26

Barber DG, Galley R, Asplin MG, De Abreu R, Warner KA, Pucko M, Gupta M, Prinsenberg S, Julien S (2009) Perennial pack ice in the southern Beaufort Sea was not as it appeared in the summer of 2009. Geophys Res Lett 36:L24501. doi:10.1029/ 2009GL041434

Barber DG, Asplin MG, Gratton Y, Lukovich JV, Galley RJ, Raddatz RL, Leitch D (2010) The International polar year (IPY) circumpolar flaw lead (CFL) system study: Overview and the physical system. Atmos Ocean 48:225-243. doi:10.3137/OC317. 2010

Bérard-Therriault L, Poulin M, Bossé L (1999) Guide d'identification du phytoplancton marin de l'estuaire du Saint-Laurent, incluant également certains protozoaires. Publ Spec Can Sci Halieut Aquat 128:1-387

Boyce DG, Lewis MR, Worm B (2010) Global phytoplankton decline over the past century. Nature 466:591-596

Boyce DG, Lewis MR, Worm B (2011) Boyce et al. reply. Nature 472:8-9

Boyd PW, Trull TW (2007) Understanding the export of biogenic particles in oceanic waters: is there consensus? Prog Oceanogr 72:276-312

Brugel S (2009) Étude des variations spatiales et temporelles du phytoplancton en mer de Beaufort: biomasse, production et structure de taille des communautés. Ph.D. Thesis, Université du Québec à Rimouski

Brugel S, Nozais C, Poulin M, Tremblay JÉ, Miller LA, Simpson KG, Gratton Y, Demers S (2009) Phytoplankton biomass and production in the southeastern Beaufort Sea in autumn 2002 and 2003. Mar Ecol Prog Ser 377:63-77

Buesseler KO, Boyd PW (2009) Shedding light on processes that control particle export and flux attenuation in the twilight zone of the open ocean. Limnol Oceanogr 54:1210-1232 
Carlotti F, Giske J, Werner F (2000) Modeling zooplankton dynamics. In: Haris RP, Wiebe PH, Lenz J, Skoldal H, Huntley ME (eds) ICES zooplankton methodology manual. Academic Press, London, pp 571-667

Carmack EC, Macdonald RW (2002) Oceanography of the Canadian Shelf of the Beaufort Sea: a setting for marine life. Arctic 55:29-45

Caron G, Michel C, Gosselin M (2004) Seasonal contributions of phytoplankton and fecal pellets to the organic carbon sinking flux in the North Water (northern Baffin Bay). Mar Ecol Prog Ser 283:1-13

Comiso JC, Parkinson CL, Gersten R, Stock L (2008) Accelerated decline in Arctic sea ice cover. Geophys Res Lett 35:L01703. doi:10.1029/2007GL031972

Darby DA (2003) Sources of sediment found in sea ice from the western Arctic Ocean, new insights into processes of entrainment and drift patterns. J Geophys Res 108:3257. doi: 10.1029/2002JC001350

Darnis G, Barber DG, Fortier L (2008) Sea ice and the onshoreoffshore gradient in pre-winter zooplankton assemblages in south-eastern Beaufort Sea. J Mar Syst 74:994-1011. doi: 10.1016/j.jmarsys.2007.09.003

Dittmar T, Kattner G (2003) The biogeochemistry of the river and shelf ecosystem of the Arctic Ocean: a review. Mar Chem 83:103-120

Dunton KH, Weingartner T, Carmack EC (2006) The nearshore western Beaufort Sea ecosystem: circulation and importance of terrestrial carbon in arctic coastal food webs. Prog Oceanogr $71: 362-378$

Engel A (2004) Distribution of transparent exopolymer particles (TEP) in the northeast Atlantic Ocean and their potential significance for aggregation processes. Deep-Sea Res Part I 51:83-92

Engel A, Passow U (2001) Carbon and nitrogen content of transparent exopolymer particles (TEP) in relation to their Alcian Blue adsorption. Mar Ecol Prog Ser 219:1-10

Forest A, Sampei M, Hattori H, Makabe R, Sasaki H, Fukuchi M, Wassmann P, Fortier L (2007) Particulate organic carbon fluxes on the slope of the Mackenzie shelf (Beaufort Sea): physical and biological forcing of shelf-basin exchanges. J Mar Syst 68:39-54. doi:10.1016/j.jmarsys.2006.10.008

Forest A, Sampei M, Makabe R, Sasaki H, Barber D, Gratton Y, Wassmann P, Fortier L (2008) The annual cycle of particulate organic carbon export in Franklin Bay (Canadian Arctic): environmental control and food implications. J Geophys Res 113:C03S05. doi:10.1029/2007JC004262

Forest A, Bélanger S, Sampei M, Sasaki H, Lalande C, Fortier L (2010) Three-year assessment of particulate organic carbon fluxes in Amundsen Gulf (Beaufort Sea): satellite observations and sediment trap measurements. Deep-Sea Res Part I 57:125-142

Forest A, Galindo V, Darnis G, Pineault S, Lalande C, Tremblay J-É, Fortier L (2011a) Carbon biomass, elemental ratios (C:N) and stable isotopic composition $\left(\delta^{13} \mathrm{C}, \delta^{15} \mathrm{~N}\right)$ of dominant calanoid copepods during the winter-to-summer transition in the Amundsen Gulf (Arctic Ocean). J Plankton Res 33:161-178. doi: 10.1093/plankt/fbq103

Forest A, Tremblay JÉ, Gratton Y, Martin J, Gagnon J, Darnis G, Sampei M, Fortier L, Ardyna M, Gosselin M, Hattori H, Nguyen D, Maranger R, Vaqué D, Pedrós-Alió C, Sallon A, Michel C, Kellogg C, Deming J, Shadwick E, Thomas H, Link H, Archambault P, Piepenburg D (2011b) Biogenic carbon flow pathways in the planktonic food web of the Amundsen Gulf (Arctic Ocean): a synthesis of field measurements and inverse modeling analyses. Prog Oceanogr. doi:10.1016/j.pocean.2011. 05.002
Gardner WD (2000) Sediment trap sampling in surface waters: issues and recommendations. In: Hansen RB, Ducklow HW, Field JG (eds) The changing ocean carbon cycle: a mid-term synthesis of the joint global ocean flux study. Cambridge University Press, Cambridge, pp 240-281

Goericke R, Frye B (1994) Variations of marine plankton $\delta^{13} \mathrm{C}$ with latitude, temperature and dissolved $\mathrm{CO}_{2}$ in the world ocean. Global Biogeochem Cycles 8:85-90

Goñi MA, Yunker MB, Macdonald RW, Eglinton TI (2000) Distribution and sources of organic biomarkers in arctic sediments from the Mackenzie River and Beaufort Shelf. Mar Chem 71:23-51

González HE, Smetacek V (1994) The possible role of the cyclopoid copepod Oithona in retarding vertical flux of zooplankton faecal material. Mar Ecol Prog Ser 113:233-246

Gosselin M, Levasseur M, Wheeler P, Horner R, Booth B (1997) New measurements of phytoplankton and ice algal production in the Arctic Ocean. Deep-Sea Res Part II 44:1623-1644

Gosselin M, Brugel S, Demers S, Juul-Pedersen T, Larouche P, LeBlanc B, Michel C, Nozais C, Poulin M, Price N, Riedel A, Różańska M, Simpson K, Tremblay JÉ (2008) Light, nutrients and primary production. In: Fortier L, Barber DG, Michaud J (eds) On thin ice: a synthesis of the Canadian Arctic Shelf Exchange Study (CASES). Aboriginal Issues Press, Winnipeg, pp 69-83

Gradinger R, Bluhm B (2005) Arctic Ocean exploration 2002. Polar Biol 28:169-170

Grebmeier JM, Overland JE, Moore SE, Farley EV, Carmack EC, Cooper LW, Frey KE, Helle JH, McLaughlin FA, McNutt SL (2006) A major ecosystem shift in the northern Bering Sea. Science 311:1461-1464

Guo L, Ping CL, Macdonald RW (2007) Mobilization pathways of organic carbon from permafrost to arctic rivers in a changing climate. Geophys Res Lett 34:L13603. doi:10.1029/2007GL 030689

Hill PR, Blasco SM, Harper JR, Fissel DB (1991) Sedimentation in the Canadian Beaufort Shelf. Cont Shelf Res 11:821-842

Hillebrand H, Dürselen CD, Kirschtel D, Pollingher U, Zohary T (1999) Biovolume calculation for pelagic and benthic microalgae. J Phycol 35:403-424

Hodal H, Kristiansen S (2008) The importance of small-celled phytoplankton in spring blooms at the marginal ice zone in the northern Barents Sea. Deep-Sea Res Part II 55:2176-2185

Holmes RM, McClelland JW, Peterson BJ, Shiklomanov IA, Shiklomanov AI, Zhulidov AV, Gordeev VV, Bobrovitskaya NN (2002) A circumpolar perspective on fluvial sediment flux to the Arctic Ocean. Global Biogeochem Cycles 16:1098. doi:10.1029/ 2001GB001849

Horner RA (2002) A taxonomic guide to some common marine phytoplankton. Biopress Ltd, Bristol

IPCC (2007) Climate change 2007: The physical science basis. Contribution of working group I to the fourth assessment report of the intergovernmental panel on climate change. Cambridge University Press, Cambridge

Juul-Pedersen T, Michel C, Gosselin M (2008) Influence of the Mackenzie River plume on the sinking export of particulate material on the shelf. J Mar Syst 74:810-824. doi:10.1016/j. jmarsys.2008.02.001

Juul-Pedersen T, Michel C, Gosselin M (2010) Sinking export of particulate organic material from the euphotic zone in the eastern Beaufort Sea. Mar Ecol Prog Ser 410:55-70

Kauffmann DS, Schneider DP, McKay NP, Ammann CM, Bradley RS, Briffa KR, Miller GH, Otto-Bliesner BL, Overpeck JT, Vinther BM, Arctic Lakes 2 K Project Members (2009) Recent warming reverses long-term Arctic cooling. Science 325:12361239 
Kellogg CTE, Carpenter SD, Renfro AA, Sallon A, Michel C, Cochran JK, Deming JW (2011) Evidence for microbial attenuation of particle flux in the Amundsen Gulf and Beaufort Sea: elevated hydrolytic enzyme activity on sinking aggregates. Polar Biol doi:10.1007/s00300-011-1015-0

Kirchman DL, Hill V, Cottrell MT, Gradinger R, Malmstrom RR, Parker A (2009) Standing stocks, production and respiration of phytoplankton and heterotrophic bacteria in the western Arctic Ocean. Deep-Sea Res Part II 56:1237-1248

Klein B, LeBlanc B, Mei ZP, Beret R, Michaud J, Mundy CJ, von Quillfeldt CH, Garneau MÈ, Roy S, Gratton Y, Cochran JK, Bélanger S, Larouche P, Pakulski JD, Rivkin RB, Legendre L (2002) Phytoplankton biomass, production and potential export in the North Water. Deep-Sea Res Part II 49:4983-5002

Knap A, Michaels A, Close A, Ducklow H, Dickson A (1996) Protocols for the joint global ocean flux study (JGOFS) core measurements. JGOFS Report Nr. 19. Reprint of the IOC Manuals and Guides No. 29, UNESCO, Bergen

Krembs C, Eicken H, Junge K, Deming J (2002) High concentrations of exopolymeric substances in Arctic winter sea ice: implications for the polar ocean carbon cycle and cryoprotection of diatoms. Deep-Sea Res Part I 49:2163-2181

Lalande C, Lepore K, Cooper L, Grebmeier J, Moran S (2007) Export fluxes of particulate organic carbon in the Chukchi Sea: a comparative study using ${ }^{234} \mathrm{Th} /{ }^{238} \mathrm{U}$ disequilibria and drifting sediment traps. Mar Chem 103:185-196

Lalande C, Bélanger S, Fortier L (2009a) Impact of a decreasing sea ice cover on the vertical export of particulate organic carbon in the northern Laptev Sea, Siberian Arctic Ocean. Geophys Res Lett 36:L21604. doi:10.1029/2009GL040570

Lalande C, Forest A, Barber DG, Gratton Y, Fortier L (2009b) Variability in the annual cycle of vertical particulate organic carbon export on Arctic shelves: contrasting the Laptev Sea, Northern Baffin Bay and the Beaufort Sea. Cont Shelf Res 29:2157-2165

Li WKW, McLaughlin FA, Lovejoy C, Carmack EC (2009) Smallest algae thrive as the Arctic Ocean freshens. Science 326:539

Lund JWG, Kipling C, Le Cren ED (1958) The inverted microscope method of estimating algal number and the statistical basis of estimations by counting. Hydrobiologia 11:143-170

Macdonald RW, Naudi SW, Yunker MB, Gobeil C (2004) The Beaufort Sea: distribution, sources, fluxes and burial of organic carbon. In: Stein R, Macdonald RW (eds) The organic carbon cycle in the Arctic Ocean. Springer, Berlin, pp 177-192

Magen C, Chaillou G, Crowe SA, Mucci A, Sundby B, Gao A, Makabe R, Sasaki H (2010) Origin and fate of particulate organic matter in the southern Beaufort Sea-Amundsen Gulf region, Canadian Arctic. Est Coast Shelf Sci 86:31-41

Meiners K, Gradinger R, Fehling J, Civitarese G, Spindler M (2003) Vertical distribution of exopolymer particles in sea ice of the Fram Strait (Arctic) during autumn. Mar Ecol Prog Ser 248:1-13

Menden-Deuer S, Lessard EJ (2000) Carbon to volume relationships for dinoflagellates, diatoms, and other protist plankton. Limnol Oceanogr 45:569-579

Montes-Hugo M, Doney SC, Ducklow HW, Fraser W, Martinson D, Stammerjohn SE, Schofield O (2009) Recent changes in phytoplankton communities associated with rapid regional climate change along the western Antarctic Peninsula. Science 323:1470-1473

Morata N, Renaud P, Brugel S, Hobson K, Johnson B (2008) Spatial and seasonal variations in the pelagic-benthic coupling of the southeastern Beaufort Sea revealed by sedimentary biomarkers. Mar Ecol Prog Ser 371:47-63. doi:10.3354/meps07677

Mucci A, Lansard B, Miller LA, Papakyriakou TN (2010) $\mathrm{CO}_{2}$ fluxes across the air-sea interface in the southeastern Beaufort Sea: ice-free period. J Geophys Res 115:C04003. doi:10.1029/2009 JC005330

Mundy CJ, Gosselin M, Ehn J, Gratton Y, Rossnagel A, Barber DG, Martin J, Tremblay JÉ, Palmer M, Arrigo KR, Darnis G, Fortier L, Else B, Papakyriakou T (2009) Contribution of under-ice primary production to an ice-edge upwelling phytoplankton bloom in the Canadian Beaufort Sea. Geophys Res Lett 36:L17601. doi:10.1029/2009GL038837

Naidu AS, Scalan RS, Feder HM, Goering JJ, Hameedi MJ, Parker PL, Behrens EW, Caughey ME, Jewett SC (1993) Stable organic carbon isotopes in sediments of the North Bering-South Chukchi Seas, Alaskan Soviet Arctic Shelf. Cont Shelf Res 13:669-691

Naidu AS, Cooper LW, Finney BP, Macdonald RW, Alexander C, Semiletov IP (2000) Organic carbon isotope ratios $\delta^{13} \mathrm{C}$ of Arctic Amerasian Continental shelf sediments. Int J Earth Sci 89:522532

NSIDC (2010) National snow and ice data center. Arctic Sea ice news \& analysis. http://nsidc.orf/arcticseaicenews/index.html

O’Brien MC, Macdonald RW, Melling H, Iseki K (2006) Particles fluxes and geochemistry on the Canadian Beaufort Shelf: implications for sediment transport and deposition. Cont Shelf Res 26:41-81

Olli K, Riser CW, Wassmann P, Ratkova T, Arashkevich E, Pasternak A (2002) Seasonal variation in vertical flux of biogenic matter in the marginal ice zone and the central Barents Sea. J Mar Syst 38:189-204

Olli K, Wassmann P, Reigstad M, Ratkova TN, Arashkevich E, Pasternak A, Matrai PA, Knulst J, Tranvik L, Klais R, Jacobson A (2007) The fate of production in the central Arctic Oceantop-down regulation by zooplankton expatriates? Prog Oceanogr 72:84-117

Pabi S, van Dijken GL, Arrigo KR (2008) Primary production in the Arctic Ocean, 1998-2006. J Geophys Res 113:C08005. doi: 10.1029/2007JC004578

Parsmore M, Costerton JW (2003) Biofilms bacterial signaling and their ties to marine biology. J Ind Microbiol Biotechnol 30:407-413

Parsons TR, Maita Y, Lalli CM (1984) A manual of chemical and biological methods for seawater analysis. Pergamon Press, Toronto

Parsons TR, Webb DG, Rokeby BE, Lawrence M, Hopky GE, Chiperzak DB (1989) Autotrophic and heterotrophic production in the Mackenzie river/Beaufort Sea estuary. Polar Biol 9:261-266

Passow U (2002) Transparent exopolymer particles (TEP) in aquatic environments. Prog Oceanogr 55:287-333

Passow U, Alldredge AL (1994) Distribution, size and bacterial colonization of transparent exopolymer particles (TEP) in the ocean. Mar Ecol Prog Ser 113:185-198

Passow U, Alldredge AL (1995) A dye-binding assay for the spectrophotometric measurement of transparent exopolymer particles (TEP). Limnol Oceanogr 40:1326-1335

Peterson BJ, Holmes RM, McClelland JW, Vorosmarty CJ, Lammers RB, Shiklomanov AI, Shiklomanov IA, Rahmstorf S (2002) Increasing river discharge to the Arctic Ocean. Science 298:21712173

Polyak L, Alley RB, Andrews JT, Brigham-Grett J, Cronin TC, Darby D, Dyke AS, Fitzpatrick JJ, Funder S, Holland M, Jennings AE, Miller GH, O'Regan M, Savelle J, Serreze M, St. John K, White JWC, Wolff E (2010) History of sea ice in the Arctic. Quat Sci Rev 29:1757-1778. doi:10.1016/j.quascirev.2010.02.010

Putt M, Stoecker DK (1989) An experimentally determined carbon: volume ratio for marine oligotrichous ciliates from estuarine and coastal waters. Limnol Oceanogr 34:1097-1103

Rachold V, Eicken H, Gordeev VV, Grigoriev MN, Hubberten H-W, Lisitzin AP, Shevchenko VP, Schirrmeister L (2004) Modern terrigenous organic carbon input to the Arctic Ocean. In: Stein R, 
Macdonald RW (eds) The organic carbon cycle in the Arctic Ocean. Springer, Berlin, pp 33-55

Redfield AC, Ketchum BH, Richards FA (1963) The influence of organisms on the composition of sea water. In: Hill MN (ed) The sea. Wiley, New York, pp 26-77

Reigstad M, Wexels Riser C, Wassmann P, Ratkova T (2008) Vertical export of particulate organic carbon: attenuation, composition and loss rates in the northern Barents Sea. Deep-Sea Res Part II 55:2308-2319

Riedel A, Michel C, Gosselin M (2006) Seasonal study of sea-ice exopolymeric substances on the Mackenzie shelf: implications for transport of sea-ice bacteria and algae. Aquat Microb Ecol 45:195-206

Riedel A, Michel C, Gosselin M, LeBlanc B (2007) Enrichment of nutrients, exopolymeric substances and microorganisms in newly formed sea ice on the Mackenzie shelf. Mar Ecol Prog Ser 342:55-67

Rivkin RB, Legendre L (2001) Biogenic carbon cycling in the upper ocean: effects of microbial respiration. Science 291:2398-2400

Sampei M, Sasaki H, Makabe R, Forest A, Hattori H, Tremblay J-É, Gratton Y, Fukuchi M, Fortier L (2011) Production and retention of biogenic matter in the southeast Beaufort Sea during 2003-2004: insights from annual vertical particle fluxes of organic carbon and biogenic silica. Polar Biol 34:501-511. doi: 10.1007/s00300.010.0904.y

Serreze M, Holland M, Stroeve J (2007) Perspectives on the Arctic's shrinking sea-ice cover. Science 315:1533-1536

Seuthe L, Darnis G, Wexels Riser C, Wassmann P, Fortier L (2007) Winter-spring feeding and metabolism of Arctic copepods: insights faecal pellet production and respiration measurements in the southeastern Beaufort Sea. Polar Biol 30:427-436. doi: 10.1007/s00300-006-0199-1

Steele M, Ermold W, Zhang J (2008) Arctic Ocean surface warming trends over the past 100 years. Geophys Res Lett 35:L02614. doi:10.1029/2007GL031651

Stein R, Macdonald RW (2004) Geochemical proxies used for organic carbon source identification in Arctic Ocean sediments. In: Stein R, Macdonald RW (eds) The organic carbon cycle in the Arctic Ocean. Springer, Berlin, pp 24-32

Stroeve J, Serreze M, Drobot S, Gearheard S, Holland MM, Maslanik J, Meier W, Scambos T (2008) Arctic sea ice extent plummets in 2007. EOS Trans Am Geophys Union 89:13-20. doi:10.1029/ 2008EO02001

Tamelander T, Renaud PE, Hop H, Carroll ML, Ambrose WG, Hobson KA (2006) Trophic relationships and pelagic-benthic coupling during summer in the Barents Sea marginal ice zone, revealed by stable carbon and nitrogen isotope measurements. Mar Ecol Prog Ser 310:33-46

Tomas CR (1997) Identifying marine phytoplankton. Academic Press, San Diego

Tréguer O, Legendre L, Rivkin RB, Ragueneau O, Dittert N (2003) Water column biogeochemistry below the euphotic zone. In: Fasham MJR (ed) Ocean biogeochemistry: the role of the ocean carbon cycle in global change. Springer, Berlin, pp 145-156
Tremblay JÉ, Hattori H, Michel C, Ringuette M, Mei ZP, Lovejoy C, Fortier L, Hobson KA, Amiel D, Cochran K (2006a) Trophic structure and pathways of biogenic carbon flow in the eastern North Water Polynya. Prog Oceanogr 71:402-425

Tremblay JÉ, Michel C, Hobson K, Gosselin M, Price N (2006b) Bloom dynamics in early opening waters of the Arctic Ocean. Limnol Oceanogr 51:900-912

Tremblay G, Belzile C, Gosselin M, Poulin M, Roy S, Tremblay JÉ (2009) Late summer phytoplankton distribution along a $3500 \mathrm{~km}$ transect in Canadian Arctic waters: strong numerical dominance by picoeukaryotes. Aquat Microb Ecol 54:55-70

Verdugo P, Alldredge AL, Azam F, Kirchman DL, Passow U, Santschi PH (2004) The oceanic gel phase: a bridge in the DOMPOM continuum. Mar Chem 92:67-85

Walker TR, Grant J, Cranford P, Lintern DG, Hill P, Jarvis P, Barrell J, Nozais C (2008) Suspended sediment and erosion dynamics in Kugmallit Bay and Beaufort Sea during ice-free conditions. J Mar Syst 74:794-809

Wang M, Overland JE (2009) A sea ice free summer Arctic within 30 years? Geophys Res Lett 36:L07502. doi:10:1029/2009GL 037820

Wassmann P, Bauerfeind E, Fortier M, Fukuchi M, Hargrave B, Honjo S, Moran B, Noji T, Nöthig EM, Peinert R (2004) Particulate organic carbon flux to the Arctic Ocean sea floor. In: Stein R, Macdonald RW (eds) The organic carbon cycle in the Arctic Ocean. Springer, Berlin, pp 101-138

Wassmann P, Duarte CM, Agusti S, Sejr MK (2011) Footprints of climate change in the Arctic marine ecosystem. Glob Change Biol 17:1235-1249

Wexels Riser C, Wassmann P, Olli K, Pasternak A, Arashkevich E (2002) Seasonal variation in production, retention and export of zooplankton faecal pellets in the marginal ice zone and the central Barents Sea. J Mar Syst 38:175-188

Wexels Riser C, Reigstad M, Wassmann P, Arashkevich E, FalkPetersen S (2007) Export or retention? Copepod abundance, faecal pellet production and vertical flux in the marginal ice zone through snap shots from the northern Barents Sea. Polar Biol 30:719-730. doi:10.1007/s00300-006-0229-z

White D, Hinzman L, Alessa L, Cassano J, Chambers M, Falkner K, Francis J, Gutowski WJ, Holland M, Holmes RM, Huntington H, Kane D, Kliskey A, Lee C, McClelland J, Peterson B, Rupp TS, Straneo F, Steele M, Woodgate R, Yang D, Yoshikawa K, Zhang $\mathrm{T}$ (2007) The arctic freshwater system: changes and impacts. J Geophys Res 112:G04S54. doi:10.1029/2006JG000353

Williams WJ, Carmack EC (2008) Combined effect of wind-forcing and isobath divergence on upwelling at Cape Bathurst, Beaufort Sea. J Mar Res 66:645-663

Wotton RS (2004) The ubiquity and many roles of exopolymers (EPS) in aquatic systems. Sci Mar 68:13-21

Yang J, Comiso J, Walsh D, Krishfield D, Honjo S (2004) Stormdriven mixing and potential impact on the Arctic Ocean. J Geophys Res 109:C04008. doi:10.1029/2001JC001248

Zar JH (1999) Biostatistical analysis, 4th edn. Prentice Hall, Upper Saddle River 